\title{
Foreign mining, law and the privatization of property: a case study from Peru
}

\author{
Charis Kamphuis* \\ B.A. (Toronto), LL.B. (Saskatchewan), LL.M. (Osgoode), Ph.D. Candidate at Osgoode Hall Law School, \\ Canada and Coordinator of the Justice and Corporate Accountability Project (JCAP)
}

This article focuses on the convergence of the corporate power of Yanacocha Mine with the Peruvian State's public power, studied in relation to two interrelated and fundamental sites of power: Indigenous land rights and the regulation of the use of force. The analysis presents two international human rights litigation initiatives: the Negritos Case and the GRUFIDES Case, which illustrate the complex relationship between Peru's colonial history, Yanacocha's current status as one of the most profitable goldmines in the world, serious land rights violations, and the emergence of widespread social protest and the escalating use of private security companies by multinational mining companies. The analysis addresses four legal processes flowing from the private-public convergence: (1) the dispossession of Campesino communal land; (2) the production of Campesino consent; (3) the privatization of coercive force; and (4) the absence of effective legal remedies. The conclusion considers the significance of the case study for those who seek to use the law to engage in practices of resistance to the power configuration represented by the private-public convergence.

Keywords: Indigenous and Campesino land rights, public-private convergence, corporate impunity, state complicity, international human rights law, national legal strategies, practices of resistance

\section{INTRODUCTION}

Yanacocha Mine, located in the Cajamarca region of the Peruvian Andes, is the largest gold mine in Latin America and one of the most profitable in the world. Three shareholders own and control Yanacocha: the Peruvian Compañía de Minas Buenaventura and the International Finance Corporation (IFC) hold a minority interest; the Newmont Mining Corporation, one of the largest gold mining companies in the world, is the majority shareholder. Since Yanacocha began operations in the early 1990s, significant

* The unwavering support and commitment of Professor Shin Imai and lawyer Jesica Karina Chuquilín Figueroa was essential to completing this project. Further, it would have been impossible to tell the story recounted here without the dedicated work of numerous community members and activists in collecting the supporting documentation. It has been an honour for me to work with all of these individuals. I also benefited significantly from conversations with Alejandro Campos Garcia in my development of the conceptual approach taken here. Finally, I am grateful to Anna Grear and Evadne Grant for their excellent editorial work that greatly improved the final version of this article. An earlier version of this argument was published in Spanish in 2012 in issue 15 of the Revista Latinoamericana de Derecho Social: Universidad Nacional Autónoma de México Instituto de Investigaciones Jurídicas. All errors are my own. 
social, political and legal conflict has ensued. The primary focus of this conflict is the land occupied by Campesino Communities.

The Indigenous status of Campesino Communities in Peru is a contentious point. On numerous occasions, elements of the Peruvian State have taken the position that international law regarding Indigenous peoples does not apply because Peru has no or very few Indigenous peoples, instead its population is fundamentally mestizo or 'mixed'. ${ }^{1}$ Conversely, the Peruvian Commission for the Environment, Ecology and Andean, Amazonian, and Afro-Peruvian Peoples, together with the Inter-American Commission for Human Rights, have both considered that Peru's Campesino Communities are Indigenous people for the purposes of the application of the Peruvian Constitution and international law, respectively. ${ }^{2}$ This article agrees with the latter position and the historical account narrated here introduces elements of the legal framework that substantiates the Indigenous status of Campesino Communities. ${ }^{3}$

While important, the Indigenous status debate is somewhat peripheral to the main focus here. This article's principal contribution is to document the contemporary convergence of Yanacocha's corporate power and the Peruvian State's public power in relation to two interrelated and fundamental sites of power: land rights and the regulation of the use of force. This convergence occurs in a particular social and cultural context: the land in question is Campesino land, and the use of force at issue is exercised primarily with regard to Campesino Communities ${ }^{4}$ and their advocates. The documentary sources that tell this story were gathered in the course of preparations undertaken to support two international human rights litigation initiatives, ${ }^{5}$ by a transnational team of Campesino community members, volunteers, lawyers, and academics in Cajamarca, Lima and various Canadian cities.

1. The State's most recent statement to this effect is documented in a recent decision of the Constitutional Tribunal of Peru: Exp. No 00024-2009-PI (26 July 2011), online: Tribunal Constitucional <http://www.tc.gob.pe/jurisprudencia/2011/00024-2009-AI.html>.

2. Comisión de Pueblos Andinos, Amazónicos y Afroperuanos, Ambiente y Ecología, Proyecto de Ley de Reforma de la Constitución, Título II, Capítulo VII 'Derechos de los Pueblos Indígenas', art 96; OAS, Inter-American Commission on Human Rights, Second Report on the Situation of Human Rights in Peru, OR OEA/Ser.L/V/II.106/Doc. 59, rev (2000) at Chapter X, 'Indigenous Communities' Rights' [OAS].

3. After over two decades of right-wing governments, the recently elected left-leaning government of Ollanta Humala passed a new law in September 2011 legislating the Indigenous right to consultation recognized by the International Labour Organization's Convention 169. This new law states that Campesina and Andean Communities can be considered Indigenous peoples in accordance with the criteria outlined in that law: Law for the Right to Consultation of Indigenous and Original Peoples Recognized by Convention 169 of the International Labour Organization (ILO) (6 September 2011) art 7 [Law for the Right to Consultation].

4. In this respect, the merger of public and private power articulates with broader patterns of institutionalized ethnic, social and cultural discrimination faced by Campesino Communities, together with other Indigenous groups in Peru. The presence of multifaceted discrimination against Campesino Communities in Peru has been observed by the Inter-American Commission for Human Rights: OAS, supra n 2 at para 32. Andean high land Indigenous people remain among the poorest, most marginalized members of society: see G Hall and HA Patrinos, Indigenous Peoples, Poverty and Human Development in Latin America: 1994-2004 (World Bank, Washington 2004) [Hall and Patrinos].

5. It should be noted that due to the fact that each litigation initiative is in its preliminary phases, these documents have yet to be admitted into evidence by a court of law. The empirical documents that substantiate the story of each case are on file with the author. 
The Negritos Case, described in Part One, is a constitutional claim, currently before Peru's domestic courts, that also relies on international human rights law. The allegations in the case relate to the transfer of Campesino land interests from the Campesino Community San Andres de Negritos to Yanacocha in violation of Peruvian constitutional law and international human rights treaties. The case provides insight into the legal and social processes whereby Indigenous communities may ostensibly consent to their own dispossession.

Part Two presents a second litigation initiative, the GRUFIDES Case, currently before the Inter-American Human Rights Commission. This section begins with a brief description of the dynamics informing the emergence of widespread social protest, primarily by Campesino Communities, in response to mining expansion. This is followed by a description of the legal regime that has facilitated the concurrent proliferation of private security companies servicing multinational mining companies operating in Peru. This case study suggests that the manner in which private security companies are consequently employed to resist Campesino protest and activism points to a partial transfer of the exercise of coercive force from the state to the corporate sector. The discussion in Part Three presents this study's second major contribution, namely an account of how law is implicated in the rearrangement and legitimation of power relationships in this discrete context. It examines the specific ways that the reconstitution of the relationship between private and public power produces, and is produced by, particular legal processes. This approach is analysed and clarified in relation to conceptual, historical, and normative modes of inquiry.

The conclusion of this analysis reflects on the possible significance of this case study for lawyers and scholars interested in exploring law's capacity to strengthen resistance to the practices and power configurations that constitute the convergence of private and public power.

\section{THE EVOLUTION AND DEVOLUTION OF THE NEGRITOS CAMPESINO COMMUNITY RIGHTS}

\subsection{Origin of Negritos Community land rights in Peruvian law}

The term 'Indigenous' first appeared in Peruvian legal discourse in 1824 and 1825 when Simon Bolivar declared that 'Indigenous Peruvians' were the rightful owners of the property in their possession and, further, that their labour must flow from freely made contracts. ${ }^{6}$ A century later, 'Indigenous communities' were recognized in Peru's 1920 and 1933 Constitutions as having special communal land rights that in turn gave rise to State responsibilities to protect these rights. This continuity in terminology was broken in 1969 when Peru's Agrarian Reform Law ${ }^{7}$ declared that, from that moment forward, 'Indigenous Communities' would be referred to as 'Campesino Communities' whose members would be denominated 'comuneros' ${ }^{8}$ In addition to this change in discourse, the law purported to replace the latifundio or hacienda land

6. Simon Bolivar, President of the Republic of Colombia and liberator of Peru, Decree (4 July 1825), art 1; Simon Bolivar, President of the Republic of Colombia and liberator of Peru, Decree (8 April 1824), art 3.

7. Law No 17716, Agrarian Reform Law (1969).

8. Ibid, art 115. 
holding system with a fair property system guaranteeing social justice in the rural areas. ${ }^{9}$ The stated objective of agrarian reform was to create a just system of property and tenancy that would support the economic and social development of the nation. ${ }^{10}$

Between 1970 and 1987 the State created a legal regime to restructure the social, political and economic organization of Peru's Campesino Communities. ${ }^{11}$ This legislative framework, which largely remains in place, defines Campesino Communities as organizations composed of families that inhabit and control specific territories. Further, these families are described as having ancestral, social, economic and cultural ties expressed through communal property title, communal work, mutual support, and democratic government. ${ }^{12}$ Campesino Communities are deemed to be fundamentally democratic institutions, autonomous in their organization, communal work and use of land. ${ }^{13}$ The legislation further provides that decisions are made by way of General Assemblies and an elected Communal Directive.

Woven throughout this legislation is the centrality of the Campesino Community's land to its cultural and political structure. This territory is defined to include, inter alia, the Community's original land, the land that the Community possesses, the land set out in its property title, and land allotted by the Agrarian Reform Law. ${ }^{14}$ Communal land is given special legal protection in that it can only be alienated with the agreement of at least two-thirds of the Community and with the passage of a law approving the alienation in the interests of the Community. ${ }^{15}$ Within the legal framework of communal title, individual families can obtain 'certificates of possession', issued by the Community's governing bodies. Finally, the expropriation of communal territory is permitted, but only for the purpose of public need and utility and after the payment of a fair price. ${ }^{16}$

Agrarian reform in Peru was not conceived of in an Indigenous rights framework. Most notably, it did not incorporate the premise that Indigenous people hold inherent property rights, ${ }^{17}$ but was based on the assumption that the State has underlying title to the land and that all title emanates from the State. ${ }^{18}$ In a challenge to agrarian

9. Ibid, art 1. The terms 'latifundio' and 'hacienda' are used in the Spanish-speaking parts of the Americas to refer to a large agricultural estate owned by a wealthy landowner of Spanish origins and worked by a large number of precariously employed families of Indigenous origins. This Spanish model of property ownership was exported to the Americas in the colonial era.

10. Political Constitution of Peru, 1979, art 159.

11. Supreme Decree No 37-70-AG, Campesino Communities Special Statute (1970); Law No 24656, Campesino Communities General Law (1987); Law No 24657, The Demarcation and Titling of the Campesino Communities' Territory is Declared a National Need and a Social Interest (1987).

12. Campesino Communities General Law, ibid, art 2.

13. Ibid, art 1 .

14. Ibid, art 2 .

15. Ibid, art 7. This protection was also enshrined in article 163 of the Political Constitution of Peru 1979 until 1993 when the then president Alberto Fujimori eliminated these protections in his new and controversial Constitution.

16. Ibid.

17. Community of Mayagna (Sumo) Awas Tingni (Nicaragua) (2001), Inter-Am Ct HR (Ser C) No 79 [Awas Tingni].

18. F MacKay, 'Indigenous Land Rights: Legal Issues' in M Colchester (ed), A Survey of Indigenous Land Tenure (FAO, 2001) 80 at 81. 
reform's social justice rhetoric, some authors have taken the view that its ultimate purpose was to lay the foundation for a more capitalist, market-efficient system of agricultural production. ${ }^{19}$ In theory, the agrarian reform process was to proceed in the following way. First, State officials were to identify the land belonging to hacienda owners deemed appropriate for reform. Then, the State was to impound the land and expropriate property title from the hacienda owners. At this point, the ownership of the land reverted to the State. Finally, the State was to recognize the Campesino Community's legal personhood, demarcate its territory, and grant it communal title.

The failure of Peru's agrarian reform project is demonstrated most poignantly by the fact that over two decades after its inception, the vast majority of Campesino Communities had yet to receive registered title. ${ }^{20}$ The story of the Campesino Community San Andres de Negritos models some of the inefficiencies and irregularities endemic in Peru's agrarian reform process. In 1971 and again in 1974, the Negritos comuneros were deemed eligible for agrarian reform in relation to 14,375 hectares of land, formerly owned by a large hacienda owner. ${ }^{21}$ However, in 1975, State officials purported to sell title to Negritos land to false representatives of a neighbouring Campesino Community. ${ }^{22}$ Upon becoming aware of this fraud, in 1986 the Negritos Community actively organized to obtain State recognition and land title. ${ }^{23}$ Finally, in 1990, the Campesino Community San Andres de Negritos, consisting of 140 families, was granted legal personhood and its communal right to 14,375 hectares of land was officially recognized. ${ }^{24}$ In 1991 the Negritos Community's communal title was registered by the Public Registrar. ${ }^{25}$ More than two decades after the 1960 s social justiceoriented spirit of agrarian reform swept Peru, the Negritos Community was able to formalize its rights by way of tangible legal documents.

19. T Griffiths, 'Indigenous Peoples, Land Tenure, and Land Policy in Latin America' in P Groppo (ed), Land Reform: Land Settlement and Cooperatives (FAO, 2004) 49.

20. According to the 1994 Census, of the 5680 recognized Campesino Communities in Peru, it is estimated that only $20 \%$ have had their land properly demarcated and it is unknown how many have obtained registered title: Laureano del Castillo, 'Propiedad Rural, Titulación de Tierras y Propiedad Comunal' (1997) 26 Debate Agrario 59 [del Castillo, 'Propiedad Rural'].

21. Ministerio de Agricultura, Zona Agraria III (Trujillo), Resolución Directoral 67 ZA-111 (11 June 1971); Presidente de La República \& Ministro de Agricultura, Decreto Supremo $N^{o}$ 1230-71-AG (28 November 1974).

22. Dirección General de Reforma Agraria, Resolución Directoral No 1773-75-DGRA-AR (18 June 1975); La Dirección General de Reforma Agraria y Asentamiento Rural y el Presidente de la Comunidad Campesina de Tual, Contrato de Compra-Venta $N^{o} 1429 / 75$ (21 June 1975); La Dirección General de Reforma Agraria y Asentamiento Rural, Resolución Directoral $N^{o}$ 1026-80-DGRA/AR (1 August 1980).

23. Acta de Asamblea General y Ordinario de la Cooperativa Agraria Negritos Alto (2 February 1986); Acta de Asamblea Extraordinaria de Nuestra Cooperativa Negritos (8 February 1987); Acta de Asamblea General Extraordinaria de la Cooperativa Negritos Alto (8 August 1987); Acta de Asamblea Extraordinaria de la Cooperativa Negritos Alto (12 April 1986).

24. Unidad Agraria Departamental XI Cajamarca, Ministerio de Agricultura, Resolución Directoral $N^{o}$ 189-90-AG-UAD XI-C (12 June 1990).

25. Presidente de la Comunidad Campesina San Andrés de Negritos, Primera Inscripción de Dominio, Partida No 02111490, Tomo 314, Foja 353, Superintendencia Nacional de los Registros Públicos (11 November 1991). 


\subsection{The elimination of Negritos communal rights}

\subsubsection{The domestic context: a neo-liberal shift in public policy}

As the Negritos Community legally consolidated its land rights, Peru plunged into a process of radical legal, political and economic change. In 1990, Alberto Fujimori was elected president of Peru. Under the auspices of the World Bank and the International Monetary Fund, Fujimori immediately instituted 'shock therapy', a programme of wide-ranging neo-liberal economic and political reforms. ${ }^{26}$ Fujimori passed a dizzying array of laws to radically reduce restrictions on international trade, investment, imports and capital flow. ${ }^{27}$ Government-funded health, education and other social services were cut back or eliminated. In the wake of this restructuring, the International Monetary Fund assessed Peru to be one of the most open and liberal economies in the world. ${ }^{28}$

Fujimori's economic reforms were accompanied by significant changes to Peruvian Campesino land law. In 1991 Fujimori repealed the Agrarian Reform Law, replacing it with the Law for the Promotion of Investment in the Agrarian Sector. ${ }^{29}$ This was followed by the introduction of an agrarian land-titling programme that contemplated only individual land titling, excluding Campesino Communities from its purview. ${ }^{30}$ In 1993, Fujimori narrowly passed a new and highly controversial Constitution that significantly reduced the protection that Campesino communal land had enjoyed for the previous 73 years. ${ }^{31}$ This opened the door for a controversial new law, dubbed the 'Land Law'.32 This 1995 law reduced the content of Campesino

26. J Bury, 'Neoliberalismo, minería y cambios rurales en Cajamarca' in A Bebbington (ed), Minería, Movimientos Sociales y Respuestas Campesinos (CEPES \& IEP, Lima 2007) 49 at 50-56 [Bury, 'Cambios rurales'].

27. See for example: Legislative Decree No 662, Granting a Legally Stable Regime to Foreign Investors through the Recognition of Certain Guarantees (1991); Legislative Decree No 757, Legal Framework for the Growth of Private Investment (1991); Legislative Decree No 674, Law for the Promotion of Private Investment in State Enterprises (1991); Legislative Decree No 708, Law for the Promotion of Investments in the Mining Sector (1991).

28. Bury, 'Cambios rurales' supra n 26 at 54.

29. Legislative Decree No 653, Law for the Promotion of Investment in the Agrarian Sector (1991).

30. R Plant and S Hvalkof, Land Titling and Indigenous Peoples in Latin America (InterAmerican Development Bank, Washington DC 2001) at 3-4, 21, 58 [Plant \& Hvalkof]; M Colchester et al, 'Indigenous Land Tenure: Challenges and Possibilities' in P Groppo (ed), Land Reform: Land Settlement and Cooperatives (FAO, Rome 2004) 8 at 13; L del Castillo Pinto, 'La titulación de tierras de propiedad de comunidades Campesinos en el Perú' in P Groppo (ed), Land Reform: Land Settlement and Cooperatives (FAO, Rome 2004) 110.

31. Whereas the 1979 Political Constitution of Peru recognized Campesino Communities as 'autonomous in their organization, communal work, and the use of their land' (art 161), the 1993 Political Constitution of Peru added 'autonomous in...the use and free disposal of their land' (art 89). The addition of these words is said to undo all Indigenous historical territorial rights because it exposes their property to an aggressive capitalist market: Cletus Gregor Barié, Pueblos Indígenas y derechos constitucionales en América Latina: un panorama, 2d ed (Génesis, Le Paz, Bolivia 2003) at 495 [Barié]. Further, the requirement in the 1979 Constitution that Campesino land may only be subject to alienation and mortgage with a favourable vote of two-thirds of the community (art 163) was dropped in the 1993 Constitution.

32. Law No 26505, Law for the Promotion of Private Investment in the Development of Economic Activities on the National Territory and on Campesino and Native Community Land (1995) [Land Law]. 
rights and established a framework to facilitate the disposition of Campesino land to private investors by way of an extraordinarily expedited process of direct negotiation between mining companies and Campesino Communities in which the Community had no substantive right to refuse the investor's offer to purchase its land. ${ }^{33}$ The Land Law further guaranteed natural and legal persons, either national or foreign, 'equal access' to agrarian property. ${ }^{34}$ For the most part, this legal trajectory has continued, if not accelerated, under subsequent governments. ${ }^{35}$

The policy shifts described above coincided with the beginning of gold mining operations on Negritos land. In 1992 the construction of Yanacocha Mine began, spearheaded by the American company Newmont Mining Corporation. Yanacocha represented the first large-scale foreign direct investment in Peru since $1976 .{ }^{36}$ The Fujimori government entered into a foreign investment contract with Yanacocha which guaranteed the company a low rate of income tax and included tax-stability provisions. ${ }^{37}$ Even more significantly, the Fujimori government granted Yanacocha and other mining companies a complete exemption from royalty payments. ${ }^{38}$ In this context, Yanacocha became the largest gold mine in Latin America with some of the lowest production costs in the world. ${ }^{39}$

Beyond these policy changes, the entry of substantial private investment into Peru was facilitated by the political corruption of the Fujimori government. Evidence has emerged with regard to Yanacocha to the effect that in 1998 officials representing both the Central Intelligence Agency (CIA) and Newmont exerted significant influence on the Peruvian government in order to secure Newmont's legal rights to Yanacocha over those of a rival French company. ${ }^{40}$ These dealings were documented in secret video recordings that became public in 2000, forming part of a political scandal that lead to Fujimori's downfall. In 2009, in a number of different proceedings, the

33. del Castillo, 'Propiedad Rural', supra n 20; L del Castillo, 'La Ley de Tierras y los Límites al Derecho de Propiedad' (1995) 23 Debate Agrario 13.

34. Land Law, supra $\mathrm{n} 32$ at art 41.

35. It remains to be seen how the recently elected government will proceed in the area of land law reform, see supra $\mathrm{n} 8$. However, for an excellent overview of conflicts over market-oriented land laws in Peru from 1990 until 2006, see: P Castillo Castañeda, El Derecho a la Tierra y los Acuerdos Internacionales: el Caso de Perú (CEPES \& International Land Coalition, Lima 2009).

36. J Bury, 'Mining Mountains, Neoliberalism, Land Tenure, Livelihoods, and the Peruvian Mining Industry in Cajamarca' (2005) 37 Environment and Planning 221 at 228 [Bury, 'Mining mountains'].

37. Christian Aid, Undermining the Poor: Mineral Taxation Reforms in Latin America (September 2009) at 9, 16.

38. Ibid. Although the rules regarding tax subsidies and royalty exemptions changed following the fall of the Fujimori government in 2000, Yanacocha has refused to abide by the new laws, claiming that it is exempted by virtue of its investment contract.

39. Bury, 'Cambios rurales', supra n 26 at 67. It is Newmont's most profitable gold mine and the IFC's largest and most profitable investment in the mining sector: World Resources Institute in LJ Laplante and SA Spears, 'Out of the Conflict Zone: The Case for Community Consent Processes in the Extractive Sector' (2008) 11 Yale Human Rts \& Dev LJ 69 at 104 [Laplante and Spears]; A Bebbington et al, 'Contention and Ambiguity: Mining and the Possibilities of Development' (2008) 39 Development and Change 965 at 974 [Bebbington et al, 'Contention and Ambiguity'].

40. J Perlez and L Bergman, 'Tangled Strands in Fight Over Peru Gold Mine' (Series: The Cost of Gold: Treasure of Yanacocha), New York Times (25 October 2005) [Perlez and Bergman]. 
Peruvian Supreme Court of Justice found Fujimori guilty of a long list of crimes, including murder, crimes against humanity, corruption, bribery and illegal interception of telephone communications. ${ }^{41}$

The preceding paragraphs describe the legal and political context within which Yanacocha obtained the concession rights to the minerals located under the communal land of the Campesino Community San Andres de Negritos. In Peruvian constitutional law, mineral resources are the property of the State. ${ }^{42}$ In general, the State has interpreted this to mean that it may grant concession rights to minerals without the consent or participation of the surface property owner. ${ }^{43}$ Thus, upon granting concessions rights, the State leaves it to the concession title-holder to obtain permission from the surface owner to enter and use the land in question. In this framework, Yanacocha faced a final legal hurdle: it had to obtain the right to use the surface area of Negritos land. For this reason, questions of access to land and land rights are at the core of the Negritos Case.

In the four years following Yanacocha's arrival, the Negritos Community was systematically stripped of its land rights and finally, of its very legal existence. The Negritos Case illuminates, on the basis of formal, publicly available documentation, the role of the State and Yanacocha in the privatization of Negritos communal land in favour of Yanacocha, culminating in the attempted elimination of the Negritos Community's rights. This was done under the auspices of four legal processes: (1) the imposition of individual title; (2) the purported expropriation of land and establishment of a mining easement; (3) the purported annulment of the legal personhood of the Community; and (4) the third party invasion of communal lands. Each of these processes will be discussed in turn.

\subsubsection{The attempted elimination of rights through four legal processes}

(a) The imposition of individual title In December 1991, the Peruvian State passed a Resolution (the '1991 Resolution') to individually title approximately half of the Negritos' communal lands in favour of 92 Negritos comuneros who signed the Resolution. ${ }^{44}$

41. Exp. No 10-2001 / Acumulado No 45-2003 A.V., Supreme Court of Justice of the Republic, Special Criminal Appeals Section (7 April 2009); Exp. No AV-33-2003, Supreme Court of Justice of the Republic, Special Criminal Appeals Section (30 September 2009).

42. Political Constitution of Peru, 1993, art 66: 'The renewable and non-renewable natural resources are the heritage of the Nation. The State is sovereign in their exploitation.' Also see: Mining Law, infra n 48, Preliminary Title II: 'All of the mineral resources belong to the State, whose property is inalienable and cannot be subject to prescription.'.

43. The Regulation of the Law for the Right to Consultation does not explicitly indicate whether or not consultation rights arise in relation to the concession granting process: see Supreme Decree No. 001-2012-MC (3 April 2012). It establishes the right to consultation only where an administrative measure 'directly affects' the legal situation or collective rights of an Indigenous community (art. 3(b)) and it defines 'administrative measures' as a measure that authorizes an activity or project to begin (art. 3(i)). One interpretation of these provisions is that the Regulation does not establish a right to consultation prior to granting concession title because the concession title alone does not allow the title-holder to initiate mining activities. Other permissions are required before title-holders can begin exploration and exploitation of resources, such as the approval of an environmental impact assessment.

44. Director de la Oficina Sub-Regional IV del Región Nor-Oriental del Marañon, Ministerio de Agricultura, Resolución Directoral No 207-91-RENOM-DSR-IV-AG-C (31 Diciembre 1991). 
The other half of the Negritos' communal land was designated a 'Reserve Area', meaning that it was converted into property of the State, to be individually titled at the State's discretion. In other words, the 1991 Resolution purported to extinguish the Negritos Community's communal land interest, apparently with the consent of a sizable portion of the Community. This radical and abrupt attempt to eliminate the Negritos' communal land interest occurred a little more than a year after the Community had successfully obtained State recognition and communal title.

Why would the Negritos comuneros have consented to the elimination of their hard won communal land rights with no compensation? The Negritos Case contends that there was no such consent and that the Negritos comuneros had not understood the 1991 Resolution's legal effect. There is no evidence that the Negritos Community received an explanation of the legal significance of individual title and its implications for the comuneros' collective and individual rights. Rather, the terms of the Resolution itself indicate that State officials made serious misrepresentations to the Community in order to procure the comuneros' signatures on the 1991 Resolution.

A wealth of contextual documentary evidence further supports the strong inference that the Negritos comuneros did not understand the legal meaning or implications of individual versus communal title under Peruvian law. It is clear, for example, that the move to individual title contradicted the Community's history of communal decisionmaking, particularly its own written laws and governing documents, yet in the wake of the 1991 Resolution, the Negritos Community continued to make communal decisions with regard to its entire territory, apparently unaware that its jurisdictional authority had been eliminated by the Resolution. Finally, the written record of communal decision-making reveals that, both before and after the 1991 Resolution, the Negritos comuneros used the terms 'property title' and 'property certificate' interchangeably, regardless of the fact that these distinct legal terms respectively refer to individual and communal property arrangements.

There are a number of reasons for the Negritos Community's evident confusion as to the significance of individual title. When the 1991 Resolution was passed, close to half of the Negritos comuneros were illiterate, less than one-third had completed secondary education, while at least four-fifths relied solely on a subsistence livelihood. ${ }^{45}$ Yet this only partially explains the vulnerability of the Negritos comuneros to the imposition of an individual property regime in the face of their established communal rights. Several anthropological studies have demonstrated that Peru's Campesino Communities have complex, mixed and multilayered conceptions of property that blend communal and familial rights into different and variable arrangements. ${ }^{46}$ This highly nuanced concept of property does not fit the dichotomous view of individual and communal property as two mutually exclusive concepts. As indicated in the previous section, the first incarnation in Peruvian law of a dichotomous (arguably Western) mode of creating property relations occurred in 1969 with the Agrarian

45. The National Institute for Statistical Information, Censos Nacionales IX de Población y IV de Vivienda 1993 (INEI, Lima 1993) 314.

46. A Diez, 'Interculturalidad y Comunidades: Propiedad Colectiva y Propiedad Individual' (2003) 36 Debate Agrario 71 [Diez, Interculturalidad']; L del Castillo, 'Titulación de las Comunidades Campesinas: CEPES, ALLPA y la Problemática Comunal' (2003) 36 Debate Agrario 89 [del Castillo, 'Problemática Comunal']; Barié, supra n 31 at 492-3; R Plant and S Hvalkof, Land Titling and Indigenous Peoples in Latin America (Inter-American Development Bank, Washington DC 2001) at 15. 
Reform Law. Since then, this approach has been integral to subsequent domestic regimes; and foundational to both the protectionist legislation of the 1980s and the neo-liberal approaches commenced in 1990. Both approaches have required that, in order to maintain the special rights afforded to Campesino Communities, comuneros must accept communal title, with individual 'certificates of possession', to the exclusion of individual title.

Yet from the perspective of Campesino Communities, their territory consists of different types of land, each associated with a different blend of communal and familial ownership. The particular configuration of this blended property arrangement varies from Community to Community and according to the type of agricultural production dominant in a particular Community. Further, while a Community's use of its territory may be predominately family-based, communal conceptions of property may become more prominent where there is a need for collective action in defence of the territory. As one anthropologist has observed, for comuneros, there is no contradiction between obtaining individual title from the State, and holding a certificate of property issued by the Community. In this conception, the difference between individual title and a certificate of possession signals a difference in degree of protection rather than a difference in property rights. For comuneros, individual title signifies increased security and therefore the more titles and certificates that a family can obtain the better. ${ }^{47}$ It has been observed that comuneros tend to want individual (family) title while also desiring to conserve the Community as a communal (and legally recognized) institution. ${ }^{48}$

(b) The purported expropriation of Negritos land and establishment of a mining easement A few months after the 1991 Resolution, Yanacocha approached the Peruvian State in 1992 to request the expropriation of a portion of Negritos land in order to effect the installation of a lixiviation plant. ${ }^{49}$ In 1994 Yanacocha made a similar request for an easement in order to build dynamite platforms and access roads. ${ }^{50}$

The expropriation and the establishment of the easement followed similar procedures. In the expropriation process, the State assigned a monetary value to the land to be expropriated, summoned the parties to meet, and approved the expropriation by way of a Resolution. In the easement process, Yanacocha determined the amount of compensation and the State's role was limited to summoning the parties to meet. The new Mining Law, introduced by Fujimori in 1991, contemplated that expropriations and the establishment of easements would proceed by way of a private

47. Diez, 'Interculturalidad', ibid at 85 .

48. del Castillo, 'Problemática Comunal', supra n 46 at 93, 95.

49. Dirección General de Minería, Ministerio de Energía y Minas, Resolución Directoral $N^{o}$ 046-93-EM-DGM (15 April 1993); Documento 2350677, Expropiación Que Otorga La Comunidad Campesina San Andrés de Negritos A Favor De Minera Yanacocha Sociedad Anónima (26 April 1993) [Expropriation Document].

50. Establecimiento de Servidumbre: Que Otorgan Comunidad Campesina San Andrés de Negritos a Favor de Minera Yanacocha Sociedad Anonimia, Documento $\mathrm{N}^{\circ} 286$, Minuta $\mathrm{N}^{\mathrm{o}}$ 276 (7 February 1995) [Easement Document]. In these processes, Yanacocha and the State indirectly treated the 'Reserve Area' created by the 1991 Resolution as though it were property of the Community, even though the legal effect of the 1991 Resolution was to 'revert' the Reserve Area to the State. This contradicts the position of the State and Yanacocha taken just a few years later, and maintained to date, that the Reserve Area is property of the State. 
agreement made directly between the mining company and the property owner. ${ }^{51} \mathrm{On}$ this basis, negotiations took place directly between Yanacocha and a handful of Negritos comuneros. Purporting to represent the Negritos Community, these individuals signed the related agreements in Lima, almost 900 kilometres away from the Negritos Community. Upon completing the deal, Yanacocha transferred funds directly to the same small group of comuneros. ${ }^{52}$

There is no evidence that these funds were ever distributed to the Negritos Community in accordance with communal laws or decision-making processes. There is no evidence that the Negritos Community received information regarding the legal meaning of the land transfers, the right to equitable compensation, the estimated value of the land at issue, the benefits that Yanacocha stood to acquire, or the possible environmental impacts of the planned mining activities. Rather, the abundant documentary evidence reveals, not only that the signatories to the expropriation and easement agreements were not legitimately elected, but that they later became implicated in systematic acts of fraud, falsification of documents and intimidation in order to affect the transfer and sale of the Community's land to Yanacocha. ${ }^{53}$ The Community was collectively to rebuke several of these individuals in a series of public meetings beginning in $1996 .^{54}$

Thus, with the State's blessing, Yanacocha purported to privately contract with the Negritos Community to transfer the land interests associated with the expropriation and the easement. These private contracts contained shockingly beneficial terms for Yanacocha. Documents suggest that in 1993, 609.44 hectares of Negritos land was expropriated in favour of Yanacocha in return for approximately US\$ $30,000 .{ }^{55} \mathrm{In}$ 1995, according to documents, 800.10 hectares of Negritos land was subject to the easement requested by Yanacocha in return for approximately US\$ $18,000 .{ }^{56}$ Unknown to the Community, one month after receiving title, Yanacocha mortgaged the expropriated land for US\$ 50 million to the International Finance Corporation and a German Bank. ${ }^{57}$

51. Supreme Decree No 014-92-EM, General Mining Law (1991) at arts 130-1 [Mining Law]. 52. See Expropiación Document, supra n 49; Easement Document, supra n 50.

53. Bartolomé Pompa Terrones, Solicitud de Garantías Personales, Sub Prefecto de la Provincia de Cajamarca (10 May 1995); Bartolomé Pompa Terrones, Solicitud de Adjudicación Individual, Director de la Sub Región IV de Agricultura de Cajamarca (20 May 1995); Bartolomé Pompa Terrones, Solicita Oposición de Adjudicación de Dos Parcelas, Director de la Sub región de Cajamarca (19 June 1995); Bartolomé Pompa Terrones, Solicitud de Adjudicación de Parcela, Coordinador del Proyecto Especial de Titulación de tierras (7 August 1995); Abelina Castrejon and Rosalia Castrejon, Solicitud de Calificación y Titulación Individual de Tierras, Jefe del Proyecto Especial de Titulación de Tierras de la Sub-Región (21 November 1995); Aurelio Castrejon Soto, Oficio $N^{o}$ 029-96-TG-LP, Dirección Sub Regional Agraria de Cajamarca (21 March 1996); Maria Antonieta García Villanueva de Díaz, Apelación de Resolución, Dirección Sub Regional de Agricultura de Cajamarca (25 March 1996); Julio Melquíades Marín Rodríguez, Apelación de Resolución, Dirección Sub Regional de Agricultura de Cajamarca (26 March 1996); Orlando Flores Villanueva, Apelación de Resolución, Dirección Sub Regional de Agricultura de Cajamarca (26 March 1996).

54. Acta de Asamblea Extraordinaria del Predio Rústico Los Negritos los Posesionarios del Sector la Pajuela (10 March 1996); Acta de Asamblea Extraordinaria de los Posesionarios del Sector la Pajuela (24 March 1996).

55. See Expropriation Document, supra n 49.

56. See Easement Document, supra n 50.

57. Inscripción de Hipoteca, Sección Especial de Predios Rurales Ubicación Paraje Yanacocha Área Ha. 609.44, Tomo 231, Folio 311, Asiento 2 de los Registros Públicos (14 September 1993). 
A year later in 1994, Yanacocha obtained a second mortgage over the expropriated land to the amount of US\$ 35 million from the same two financial institutions. ${ }^{58}$

There is no question that this initial acquisition of these Negritos property interests was an essential factor in the unprecedented success and profitability that Yanacocha quickly attained. Indeed, Yanacocha had acquired the concession rights to one of the most valuable gold deposits in the world with the benefit of a foreign investment contract that guaranteed a low rate of tax and zero royalties. Further, Yanacocha acquired the corresponding surface rights to 1,209 hectares of traditional Campesino Community land for a mere US\$ 48,000, free of any additional cumbersome rights and obligations to the Community. ${ }^{59}$ Having secured this very lucrative legal arrangement, Yanacocha proceeded to obtain start-up financing loans totalling US\$ 85 million.

(c) The purported annulment of the Negritos Community's legal personhood On the heels of the expropriation and the easement, the State passed a Resolution in September 1995 purporting to annul the legal personhood of the Campesino Community San Andres de Negritos. ${ }^{60}$ The 1995 Resolution also extended the individual titling of Negritos land to almost all of Negritos communal land. The Reserve Area (property of the State) that had been created by the 1991 Resolution was reduced to 1033.97 hectares. By eliminating the Negritos Community's legal personhood and communal title, the presumed legal result of the 1995 Resolution was to eliminate all of the political, economic and cultural rights previously held by the Community.

The documentary evidence shows that the 1995 Resolution was facilitated by fundamental legal misrepresentations to the Community. State officials and Yanacocha functionaries circulated a legal opinion written by a State lawyer among Community members. ${ }^{61}$ This document defended the validity of the 1991 Resolution on individual titling. It also declared that the Negritos Community had never held a collective

58. Inscripción de Segunda Hipoteca, Sección Especial de Predios Rurales Ubicación Paraje Yanacocha Área Ha. 609.44, Tomo 231, Folio 3XX, Asiento X de los Registros Públicos (12 October 1994).

59. It is worth noting that the land pertaining to the easement and the expropriation were essential to Yanacocha's initial operations. The dynamite platforms permitted Yanacocha to set up the infrastructure needed to blast and loosen rock containing gold. The loosened rock would then be transported via the access roads to the lixiviation plant where a cyanide solution would be leached through the earth in order to separate the gold from other materials.

60. Dirección Sub Regional Agraria Cajamarca, Resolución de Dirección Sub Regional Sectorial $N^{o}$ 143-95-RENOM/AG (8 September 1995).

61. Oficina de Asesoría Jurídica del Proyecto Especial de Titulación de Tierra de la Dirección Regional Agraria de la Región Nor-Oriental del Marañon, Informe Legal No 069-95-RENOMDRA-DAJ-PETT (February 1995); Aurelio Castrejón Soto, Oficio N ${ }^{o}$ 027/ CCSANLP, Sub Director del Ministerio de Agricultura (22 March 1995); Director de la Asesoría Jurídica y el Sociólogo de Comunidades Campesinas del Proyecto Especial de Titulación de Tierra, Informe Técnico Legal, Director de la Sub Región-Cajamarca (24 April 1995); Acta de Asamblea General de la Comunidad Campesina San Andrés de Negritos 'Sector de la Pajuela' (29 April 1995); Aurelio Castrejón Soto and Lorenzo Zamora Castrejón, Renuncia en Forma Irrevocable, Director de la Sub Región Agraria Cajamarca (2 May 1995); Acta de Reunión General del Sector La Pajuela (3 May 1995); Director de la Oficina de Asesoría Jurídica, Informe de Comisión de Servicio, Director de la Sub Región Agraria de Cajamarca (5 May 1995); Director de la Oficina de Asesoría Jurídica, Informe Legal No 032-95-CTA-RENOM-GSR-CAJ-DSR-AG/OAL, Coordinador del Proyecto de Titulación de Tierras (7 June 1995). 
property right to its traditional land and that the Negritos' land rightfully belonged to the State. Together with the previously described practices of corruption and intimidation on the part of the comuneros who had signed off on the expropriation and the easement, this erroneous legal opinion led to significant conflict among Negritos comuneros.

Thus, four short years after the arrival of Yanacocha, the State purported to have annulled the legal personhood of the Negritos Community and eliminated its communal property interest. Each Negritos family was issued a document of individual title to a demarcated parcel of land. Yanacocha, one of the most powerful gold mines in the world, was conveniently free 'to solicit' the purchase of land from individual Negritos families, who had never before owned land in a free market. The subsequent land purchases are now infamous in Peru for, at best, gross unfairness, and at worst, acts of deception, abuse of power, and intimidation. ${ }^{62}$ As of 2009 , it was estimated that approximately one-third of Negritos original land interests had been transferred to Yanacocha.

In sum, the State and Yanacocha benefited from the Negritos comuneros' lack of legal knowledge and the systemic bias toward individual title in the Peruvian legal regime enabling them to facilitate the 'transfer' of land from the Community to Yanacocha in return for minimal compensation. However, in spite of the formal loss of their legal rights, the Negritos comuneros maintained their communal institutions, including regular elections of communal leadership. Together with other communities, they began to politically organize to address the mining-related issues affecting communities in the area. In 1999, the Negritos comuneros participated in the first incident of widespread Campesino protest against the continued expansion of Yanacocha. ${ }^{63}$ Further, in an effort to gain formal legitimacy for its collective claims against Yanacocha and the State, the Negritos Community officially registered its governing body with the Public Registrar in 2005 and in 2006 the comuneros approved of a modified Community Statute. ${ }^{64}$

The continued level of political organization of the Negritos Community is remarkable given that Yanacocha's presence has clearly weakened the 'social capital' of the

62. Some empirical studies have documented the general tactics adopted by Yanacocha in purchasing land from local Campesinos: S Langdon, 'Peru's Yanacocha Gold Mine: The IFC's Midas Touch?' in Profiling Problem Projects (Project Underground, Berkeley CA 2003); Bury, 'Cambios rurales', supra n 26 at 76-7; Anthony Bebbington et al, 'Mining and Social Movements: Struggles over Livelihood and Rural Territorial Development in the Andes' (2008) 36 World Development 2888 [Bebbington et al, 'Social movements']. See section 4.1., infra, for reference to a study of Yanacocha's role in facilitating the administrative processes of individual titling.

63. A Bebbington et al, 'Movimientos sociales, lazos transnacionales y desarrollo territorial rural en zonas de influencia minera: Cajamarca-Perú y Cotacachi-Ecuador" in A Bebbington (ed), Minería, Movimientos Sociales y Respuestas Campesinos (CEPES, IEP, Lima 2007) 163 at 168 [Bebbington et al, 'Movimientos sociales'], citing protests regarding an area of land called 'La Quinua', which is part of Negritos territory.

64. Acta de Asamblea General de Regularización y Elección de la Directiva Comunal (18 December 2005), Oficina Registral Cajamarca, Zona Registral No II Sede Chiclayo, Superintendencia Nacional de los Registros Públicos, Libro No 03, Fojas 23-29; Acta de Asamblea General de la Comunidad Campesina San Andrés de Negritos (6 August 2006), Oficina Registral Cajamarca, Zona Registral No II Sede Chiclayo, Superintendencia Nacional de los Registros Públicos, Libro No 03, Fojas 40-54, Partido No 02118220. 
rural communities in the area. ${ }^{65}$ The Community continually confronts the divisions generated by Yanacocha's financial influence. For example, in 2007 the Community's elected president was removed from his position and replaced by a unanimous General Assembly of Negritos comuneros when it was discovered that Yanacocha subcontracted a business owned by the president's son. The Community is adamant that its leadership maintain political and economic autonomy from Yanacocha. Further, the Community demands that Yanacocha obtain communal permission before making decisions that will affect comuneros' land or before procuring subcontracting services. ${ }^{66}$ Nonetheless, the documentation suggests that Yanacocha continues to deny the legitimacy of the elected Community authorities and consistently engages in a multitude of practices that threaten to undermine and divide the Community. ${ }^{67}$

In the face of these threats to communal cohesion, renewed communal identities, political institutions and political action in the Negritos Community are surviving, and at times perhaps even thriving, catalyzed by common concerns. Many of these concerns are beyond the scope of this article, such as the issue of environmental contamination, lack of access to employment, and the countless impacts of mining operations on comuneros' subsistence livelihoods and daily living. Other concerns will be touched on in Part Three of this article. These relate to the Community's concerted struggle for recognition and land rights vis-à-vis the State and Yanacocha. A final catalyst for communal mobilization has been the invasion of the Reserve Area by third parties. This situation is briefly outlined in the following section.

(d) Third-party invasion of communal land The 1995 Resolution purporting to annul the legal personhood of the Negritos Community carved out a Reserve Area of 1033.97 hectares of Negritos land. While the State considers the Reserve Area to be State property, the Negritos comuneros believe that it is Community property and they occupy and use it communally as grazing land for their sheep and cattle.

In 2004, third parties not belonging to the Negritos Community, presented documents to a local court and successfully received a judgment granting them ownership of land in the Reserve Area. When the Negritos Community became aware of these events in early 2006, it began civil proceedings to nullify the judgment, together with

65. J Bury, 'Minería, migración y transformaciones en los medios de subsistencia en Cajamarca, Perú' in A Bebbington (ed), Minería, Movimientos Sociales y Respuestas Campesinos (CEPES, IEP, Lima 2007) 231; Bebbington et al, 'Movimientos Sociales', ibid at 197.

66. Documentos on file with author: Comunidad Campesina San Andrés de Negritos, Solicitud, Gerente General de Asuntos Externos y Comunidades, Minera Yanacocha SRL (3 January 2008); Minera Yanacocha SRL, Carta Notarial, Comunidad Campesina San Andrés de Negritos (22 August 2007); Junta Directiva de la Comunidad Campesina San Andrés de Negritos, Escrito, Gerente General de Asuntos Externos y Comunidades de Minera Yanacocha (3 January 2008).

67. Ministerio de Energía y Minas, Oficina General de Gestión Social, Informe Trimestral Octubre - Diciembre 2009, at 40. Documents on file with author: Gerente de Desarrollo Social, Minera Yanacocha SRL, Carta Notarial, la Comunidad Campesina San Andrés de Negritos (3 January 2008); Comunidad Campesina San Andrés de Negritos, Carta No 06-2009-P.ID. CCSAN-LA-CAJ, Gobernador Regional de Cajamarca (12 June 2008); Junta Directiva de Negritos, Comunicado, la Empresa Minera Yanacocha (26 March 2007). 
criminal proceedings alleging the falsification of documents and usurpation of communal land. Nonetheless, the third party invaders began to occupy land in the Reserve Area, preventing the entry of Negritos comuneros by threatening to use firearms. These third parties also began to threaten and harass Negritos Community leaders. In response, the Negritos Community made numerous appeals for police protection. The Community also requested police accompaniment in order to conduct a communal inspection of the Reserve Area in an effort to identify the extent of the invasion. This peaceful method for inspecting communal land, referred to as a 'rodeo', is a traditional communal practice described and codified in the Negritos Community's governing documents. When requests for police protection were consistently ignored, 250 Negritos comuneros undertook a rodeo of the Reserve Area on their own. The armed third party invaders ambushed the rodeo and at least one comunero was shot and injured.

Shortly thereafter, this violent conflict took a tragic turn when Esmundo Becerra, a leader in the opposition to Yanacocha's continued expansion into Negritos territory was assassinated. ${ }^{68}$ There has been no criminal prosecution in this case. The fact that Yanacocha's intelligence apparatus had identified Esmundo Becerra as a 'threat' will be discussed in Part II of this paper.

The Negritos Community's elected leaders continue to send letters to Yanacocha as well as State officials, voicing concerns and requesting that the company and the State recognize the Community and consult before purchasing or developing Community land, including land in the Reserve Area. The use of formal channels has largely failed to deliver a productive response. As a result, the Negritos Community has turned to mass civil disobedience, most typically blockading the local highway that Yanacocha relies upon for its operations. However, these informal actions have also had a limited impact and frequently result in criminal charges being laid against the Community's leadership.

In March 2007, approximately 200 Negritos comuneros united in a General Assembly to authorize the local NGO, GRUFIDES, to commence a legal investigation into the abuses committed by the Peruvian State and Yanacocha in relation to the expropriation, the easements and the Reserve Area. The next section documents the highly repressive response of Yanacocha and the Peruvian State to the rise in Campesino Community organizing and the prominence of GRUFIDES' work.

\section{THE EMERGENCE AND REPRESSION OF GRUFIDES' HUMAN RIGHTS WORK}

\subsection{The rise of Campesino Community organizing and GRUFIDES}

The Negritos Community's resurgence coincided with similar processes occurring across Peru at the turn of the $21^{\text {st }}$ century. ${ }^{69}$ After more than a decade of proliferating mining concessions and weak domestic legislation, communal organizations across

68. Frente Único de Defensa de los Interés, la Vida y el Medio Ambiente de Cajamarca, 'A Un Año del Asesinato del Líder Ecologista Esmundo Becerra' (31 October 2007), online: 'El Maletero' Red Verde Cajamarca <http://caballeroredverde.blogspot.com/2007/10/un-aodel-asesinato-del-lider.html $>$ [Frente de Defensa].

69. In 1999 the National Coordinator of Mine Affected Communities (CONACAMI) was created with the participation of activists from Cajamarca: José De Echave and Pasco-Font, Minería y Comunidades (CooperAcción, Lima 1999). 
the country have mobilized to defend communal territory and the environment. Like the Negritos Community, Campesino Communities in Peru have begun to claim the protection offered by international Indigenous rights regimes, such as the Convention concerning Indigenous and Tribal Peoples in Independent Countries ${ }^{70}$ (Convention $\left.N^{o} 169\right)$. These newly framed claims are sometimes founded on the 'rediscovery' of Indigenous identities, formerly obfuscated during the nation-building project of agrarian reform. ${ }^{71}$ They also allow Campesino Communities to access an international rights regime corresponding to their needs in the face of Peru's weakened land rights regime.

The Negritos Community's complaints against Yanacocha are similar to those raised by the company's other rural and Campesino neighbours. These relate to the conditions under which Yanacocha acquired land, fair compensation, civil treatment and greater participation in the benefits of the mine. ${ }^{72}$ As these grievances remained unresolved, the first sign of large-scale protest against Yanacocha occurred in 1999 when 6000 Campesinos, including Negritos comuneros, protested against Yanacocha's expansion to a part of Negritos territory known as La Quinua, as well as to a neighbouring area called Quilish Mountain. ${ }^{73}$

In response to this surge of activism, the local government was pressured to pass a municipal by-law in 2000, declaring Quilish a protected area. ${ }^{74}$ Support for the municipal by-law was catalysed by an environmental disaster that occurred earlier that year. ${ }^{75}$ A mining truck, subcontracted by Yanacocha, accidentally spilled approximately 330 pounds of liquid mercury on a highway in the rural district of Choropampa. ${ }^{76}$ The Choropampa accident and its mismanagement by both Yanacocha

70. Convention concerning Indigenous and Tribal Peoples in Independent Countries, Peru, 2 February 1994, International Labour Organization, Convention No 169 (entered into force 2 February 1995).

71. Alejandro Diez, 'Las Organizaciones Colectivas, los Recursos y los Pueblos Indígenas en el Perú' in Fernando Eguren (ed), Reforma agraria y desarrollo rural en la Región Andina (CEPES, Lima 2006) 111 at 124.

72. Bebbington et al, 'Social Movements', supra n 62. It is widely observed that Peru's foreign direct investment model has failed to improve the standard of living of the country's rural poor, the vast majority of whom remain either poor or extremely poor: see: Laplante and Spears, supra n 39 at 101; Bury, 'Cambios rurales', supra n 26 at 56.

73. Bebbington et al, 'Social Movements', ibid.

74. Municipal Ordinance No 012-2000-CMPC, Cajamarca Provincial Municipality.

75. C Meléndez Guerrero, 'Movilización sin movimientos. El caso de los conflictos entre comunidades y la empresa minera Yanacocha en Cajamarca' in R Grompone and M Tanaka (eds), Entre el Crecimiento Económico y la Insatisfacción Social: Las Protestas Sociales en el Perú Actual (IEP, Lima 2009) 321 at 337 [Meléndez].

76. The Choropampa environmental and human health disaster triggered a chaotic series of lawsuits and private indemnification agreements between Yanacocha and individual Campesinos. These agreements have been the subject of significant controversy. Most recently, in 2009, some of the affected municipalities signed a highly controversial settlement agreement with Yanacocha in order to terminate outstanding lawsuits against Newmont in the United States. Serious allegations against Yanacocha officials, State authorities, certain NGOs, and individual lawyers and law firms continue to cast a dark legal shadow over the Choropampa accident. Many individual Campesino claimants remain embroiled in civil claims against Yanacocha in local courts. GRUFIDES has taken responsibility for many of these remaining lawsuits, which suffer from delays, a serious lack of access to adequate legal council and inadequate funds to marshal the evidence needed to substantiate their claims. 
and State officials further offended local Campesino Communities and their growing number of allies, both nationally and internationally. ${ }^{77}$

These events set the stage for the formation of the NGO, GRUFIDES in 2001 in the city of Cajamarca. These urban activists, mostly university students, were organized and guided by Marco Arana, who at that time served as the Catholic priest of the public University parish. Offering educational, political and legal support to Campesino Communities adversely affected by Yanacocha's mining operations, GRUFIDES quickly gained considerable legitimacy among many of these Communities.

The relationship and trust between GRUFIDES and local Campesino Communities was quickly put on public display when the first large-scale confrontation occurred between Yanacocha and people from both rural and urban Cajamarca. In 2001 Yanacocha brought an action in the Peruvian Constitutional Court arguing that the municipal by-law protecting Quilish Mountain violated its constitutional right to property and freedom to work, on the basis that Yanacocha held the mineral rights, and some of the surface rights corresponding to Quilish Mountain. The Constitutional Court declared in 2003 that Yanacocha's mineral exploitation rights were compatible with the municipal by-law designating Quilish Mountain a protected area. ${ }^{78}$ Thus, the Court left the by-law intact while requiring Yanacocha to undertake an environmental impact assessment before continuing with its exploration activities in the area. Yanacocha positioned its machinery near Quilish Mountain as it waited for the Ministry of Energy and Mining to make the final decision on the environmental assessment. ${ }^{79}$ When the Ministry gave Yanacocha the green light in 2004, thousands protested in the streets of the city of Cajamarca. ${ }^{80}$ Campesino Communities mobilized to physically block Yanacocha's machinery and a general strike took place in Cajamarca. ${ }^{81}$

In the midst of this unrest, Marco Arana from GRUFIDES was proposed as mediator between community leaders on the one hand, and Yanacocha and State authorities, on the other. ${ }^{82}$ As a result of these mediations, Yanacocha withdrew, at least temporarily, its plans to exploit Quilish Mountain. As a consequence of its role in resolving the conflict, GRUFIDES' reputation as an ally of mining-affected communities gained national recognition and the 2004 National Prize in Human Rights was awarded to Marco Arana for his participation in the mediation.

However, not everyone was happy with the rising prominence of GRUFIDES as a defender of mining-affected communities. In late 2005, Canadian Lutheran World Relief was told by the Canadian government that it had to end its funding of GRUFIDES or lose its co-financing support from the Canadian government. The reason provided was that GRUFIDES' work was a foreign relations problem for Canada. ${ }^{83}$

77. For example, a Canadian activist filmed a documentary about the case, which was shown around the world and has received various international prizes: Ernesto Cabellos and Stephanie Boyd, Choropampa: The Price of Gold (Guarango Association, 2002).

78. Exps. Acumulados No 300-2002-AA/TC y Otros, Constitutional Court of Peru (7 April 2003).

79. Meléndez, supra n 75 at 338-9.

80. Bebbington et al, 'Movimientos sociales', supra n 63 at 169.

81. Laplante and Spears, supra n 39 at 105; Bebbington et al, 'Movimientos sociales', ibid at 169-70.

82. Perlez and Bergman, supra n 40; Meléndez, supra n 75 at 345-6.

83. A Bebbington et al, Mining and Development in Peru: With Special Reference to the Rio Blanco Project, Piura (Peru Support Group, London 2007) at 48-9 [Bebbington et al, Rio Blanco Project]. 
As a result, Lutheran World Relief terminated GRUFIDES' funding in October 2005 in the middle of the agreed project cycle. The terminated funds represented approximately one-third of GRUFIDES' budget at the time.

The behind-the-scenes manoeuvring of the Canadian government was only the beginning of the problems GRUFIDES was to confront. The GRUFIDES Case alleges that in the aftermath of Quilish, Yanacocha escalated its efforts to repress the environmental and social activism growing within Campesino Communities and so closely identified with GRUFIDES' NGO work. Given that this repression occurred primarily through a web of contracted and sub-contracted private security services, a brief introduction to the phenomena of private security in Peru follows.

\subsection{The privatization and internationalization of private security in Peru}

The sustained level of Campesino protest in Cajamarca indicates that public and private institutions to date have not responded effectively to the demands of miningaffected communities. This uncomfortable standoff mirrors similar events in the rest of the country. While some mining companies in Peru have assumed an amicable approach to dialogue with Campesino Communities, the more conservative institutions have resisted the increasing power of these social movements. ${ }^{84}$ The level of violent conflicts in Peru between Communities, mining companies and the State has escalated dramatically since the year $2000 .{ }^{85}$ In 2006 alone, 83 attacks on environmental and human rights defenders were reported. ${ }^{86}$ Private security companies are increasingly the principal mediators of these violent confrontations.

It has been observed that the proliferation of private security companies is a frequent consequence of the neo-liberal restructuring of economic and social policies. ${ }^{87}$ This is certainly the case in Peru where there has been an enormous expansion of private security companies since the neo-liberal shift initiated in the early $1990 \mathrm{~s} .{ }^{88}$ Since then, successive Peruvian governments have not increased the number of public

84. J De Echave C, Los Retos Actuales del Movimiento Social Vinculado a la Lucha por los Derechos de las Comunidades Frente a las Industrias Extractivas: El Caso Peruano' Paper presented at Conference Rethinking Extractive Industry: Regulation Dispossession and Emerging Claims, York University, Toronto, March 2009) at 9 [unpublished], online: CERLAC <http:// www.yorku.ca/cerlac/EI/papers/De\%20Echave.pdf> [De Echave].

85. In 2007 there were 35 recorded separate ongoing conflicts related to mining in Peru and an average of 30 reported incidents of conflict per month: see Laplante and Spears, supra n 39 at 99 .

86. JL Gómez del Prado, Report of the Working Group on the use of mercenaries as a means of violating human rights and impeding the exercise of the right of peoples to self-determination, UNGAHRC, 7th Sess, UN Doc A/HRC/7/7/Add.2 (2008) at 15 [UN Working Group].

87. B Campbell, 'Good Governance, Security and Mining in Africa' (2006) 21 Minerals \& Energy - Raw Materials Report 31 [Campbell]; AP Kontos, "Private” Security Guards: Privatized Force and State Responsibility under International Human Rights Law' (2004) 4 NonState Act \& Int'l L 199; M Ungar, 'The Privatization of Citizen Security in Latin America: From Elite Guards to Neighborhood Vigilantes (2007) 34 Social Justice 20; RP Weiss, 'From Cowboy Detectives to Soldiers of Fortune: Private Security Contracting and its Contradictions on the New Frontiers of Capitalist Expansion' (2007) 34 Social Justice 1.

88. In 1994 Fujimori introduced Peru's first law pertaining to the regulation of private security services: Supreme Decree No 005-94-IN, Approval of the Regulation for Private Security Services (12 December 1994). This law remained in place until 2006 when Law No 28879, Private Security Services Act was introduced. 
police officers. ${ }^{89}$ In 2008 the number of private security guards in Peru was estimated to be 100,000 , outnumbering the public police force of about $92,000 .^{90}$ It is also believed that half of the private security guards in Peru work for companies in the informal sector, many of which provide security to multinational companies. ${ }^{91}$

There is a close relationship in Peru between State officials and private security companies. In many cases, former members of the Armed Forces or the National Police Force are the owners or senior managers of these companies. ${ }^{92}$ Moreover, off-duty police officers are permitted to work for private security companies while using State property such as weapons, uniforms and ammunition. ${ }^{93}$

The private security company known as Forza exemplifies these trends in Peru. Forza was created in 1991 with the objective of offering complete 'corporate security' services to diverse companies in Peru with a specialization in the industrial, mining and energy sector. ${ }^{94}$ Retired personnel from the Armed Forces who specialized in subversion and espionage work for the Fujimori government founded, and continue to manage, Forza. ${ }^{95}$ In 1993 Forza became Yanacocha's exclusive private security company. ${ }^{96}$ In 2007 Securitas, one of the largest transnational private security corporations in the world, ${ }^{97}$ acquired Forza as part of its expansion into the Latin American private security market. According to the Securitas website, its decision to enter the Peruvian security market through the acquisition of Forza was decisively influenced by Forza's 'prestige, experience and position in the Peruvian market'. ${ }^{98}$

While private security companies in Peru have been servicing corporations for the last two decades, they have recently become implicated in the harassment and intimidation of human rights organizations working to defend the economic, social and environmental rights of mining-affected communities. ${ }^{99}$ Anti-activist and anti-environmentalist discourse is also increasingly being used in an effort to discredit activists and construct them as violent, leftwing, anti-mining, anti-development, terrorist conspirators. ${ }^{100}$

89. UN Working Group, supra n 86 at 13.

90. Ibid at 5,13 .

91. Ibid at 6 .

92. Ibid at $14,21$.

93. Ibid at $14,21$.

94. Securitas Peru, online: Securitas <http://www.securitas.com/pe/es-pe/About-Us/SecuritasPeru/>.

95. Edmundo Cruz, 'Nuevas pruebas acusan a Forza', La Republica (3 February 2007) [Cruz, 'Nuevas Pruebas'].

96. Forza also provides security services to the banking and finance industry, the mining, petroleum and energy sector, as well as the construction sector. ${ }^{96}$ It clients have included the British Embassy, the National Mining, Oil and Energy Association, the Inter-American Development Bank, the Standard Bank London Limited, as well as subsidiaries of Coca Cola, Eli Lilly, and Hewlett Packard: Forza, online: CreditosPeru <http://www.creditosperu. com.pe/pp-forza-s-a.php>.

97. Securitas has $12 \%$ of the global market share and employs over 240,000 individuals to offer services in over 40 countries on every continent: About Us, online: Securitas <http:// www.securitas.com/en/About-Securitas/>.

98. About Us, Securitas Peru, online: Securitas <http://www.securitas.com/pe/es-pe/AboutUs/Securitas-Peru/>.

99. UN Working Group, supra n 86 at 5, 15, 21.

100. De Echave, supra $\mathrm{n}$ 69. UN Working Group, supra $\mathrm{n} 86$ at 19, 21. The most notorious example of this discourse was provided by an article published by the President Alan Garcia in Peru's largest national newspaper: A García, 'El Perro del Hortelano', El Comercio (28 October 2008). 
The aggression of private security companies against human rights defenders is mirrored in the public sphere. In 2006 and again in 2007 the State escalated its efforts to criminalize public protest by introducing modifications to the Criminal Code which distorted and broadened existing criminal offences to capture activities related to social protest. Draconian prison sentences were created for 'the obstruction of public services', which includes protest-related activities such as road blockades. ${ }^{101}$ Most dramatically, in 2007, police officers and military personnel who murder citizens while carrying out their duties, such as controlling public protest, were guaranteed immunity from prosecution. ${ }^{102}$ This was the first time in Peruvian history that this type of immunity has been legally codified.

Ironically, while the public exercise of coercive force has been strengthened, it has also been privatized. Yanacocha is among a number of mining companies in Peru that has negotiated a 'Cooperation Agreement' with the Peruvian National Police Force. This agreement establishes the terms within which the police force will offer security and protection to Yanacocha in exchange for 'support' from the company. ${ }^{103}$ In this framework, the police force commits to furnishing the company with a rotating fleet of uniformed and armed off-duty officers available 24 hours a day to 'prevent, detect and neutralize risks' putting the mine or its personnel in danger. In return, Yanacocha provides the police officers with life insurance and equipment. It also promises to cover the cost of legal representation for officers who become involved in a legal process due to an act committed while performing their duties in the service of the company. Finally, the company makes two regular payments to the police force, first to cover the officers' salaries and second, a monthly contribution to the institution equivalent to $20 \%$ of these salaries. In addition, the police force reserves the right to request further financial support from Yanacocha on an ongoing basis. The full extent of Yanacocha's economic support for the police force is unknown.

\subsection{Yanacocha, Forza, and the persecution of GRUFIDES activists}

A violent clash in 2006 between the mining-affected community of Combayo and Yanacocha triggered the events which gave rise to the GRUFIDES Case. In August of that year, approximately 100 Campesinos initiated a highway blockade while 500 more protested peacefully in the streets of Combayo. ${ }^{104}$ The protestors nominated GRUFIDES to assist in efforts to engage in dialogue with Yanacocha. ${ }^{105}$ They were frustrated by Yanacocha's failure to fulfil various commitments and its unresponsiveness to

101. W Ardito Vega et al, Serios Peligros para los Derechos Humanos: La Criminalización de la Protesta en el Gobierno de Alan García (Asociación Pro Derechos Humano, Lima 2008). 102. Legislative Decree No 982 (22 July 2007), art 1, modifying art 20, clause 11 of the Criminal Code.

103. Agreement on file with author. Also see: G Costa, Comprehensive Review of Minera Yanacocha's Policies Based on the Voluntary Principles of Security and Human Rights (12 May 2009) at 11 [Costa, Comprehensive Review]. For a more detailed legal analysis of these agreements see: C Kamphuis, 'Foreign Investment and the Privatization of Coercion: the Forza Security Company in Peru' (2012) 37:2 Brooklyn Journal of International Law 459-508.

104. 'Yanacocha anuncia suspensión total de sus actividades', La Republica (28 August 2006) ['Yanacocha anuncia suspensión']; E Jara and H Holguín, 'Han tomado una decisión apresurada', La Republica (29 August 2006).

105. 'Campesinos de Combayo y minera Yanacocha llegan a primer acuerdo', La Republica (29 August 2006). 
complaints of environmental contamination. ${ }^{106}$ Yanacocha responded by deploying approximately 190 armed officers to put an end to the blockade. ${ }^{107}$ This security force consisted of Forza officers, together with off-duty police officers contracted by Yanacocha. ${ }^{108}$

In violent confrontations between these security forces and Campesino protestors, a Campesino by the name of Isidro Llanos was shot and killed. ${ }^{109} \mathrm{~A}$ few weeks after Llanos' death, the on-going blockade forced Yanacocha to halt its operations for three days. ${ }^{110}$ At this point, with Yanacocha incurring economic losses, high-level State officials intervened and requested that GRUFIDES act as the official mediator of the conflict. ${ }^{111}$ Although the conflict was eventually resolved, the officers who shot and killed Isidro Llanos were not prosecuted due to a 'lack of evidence'. ${ }^{112}$ Yanacocha is reportedly providing his surviving family members with private compensation pursuant to a confidential agreement. ${ }^{113}$

The violent response to the Campesino blockade in Combayo had a counterpart in the city of Cajamarca. In a series of press conferences, Yanacocha's manager of external affairs repeatedly and publicly accused GRUFIDES of manipulating Campesino Communities and exacerbating the Combayo conflict. This was followed by antiGRUFIDES marches, organized and directed by a number of Yanacocha's senior managers and allegedly funded by Yanacocha. ${ }^{114}$ The participants in these marches were primarily Yanacocha employees and their family members. Some marchers were reportedly told to participate in the marches or risk losing their employment. ${ }^{115}$

The anti-GRUFIDES marches took place continuously over a period of several days, coinciding with the temporary closure of Yanacocha due to the Combayo protest. The marchers primarily remained stationed in front of the GRUFIDES office, harassing, intimidating, threatening and insulting GRUFIDES personnel. ${ }^{116}$ Alarmingly, in the face of these acts, the public police force failed to intervene and provide GRUFIDES personnel with protection. ${ }^{117}$ GRUFIDES personnel were essentially trapped in their

106. Ibid.; A Ramos 'Yanacocha paraliza operaciones en Combayo por los conflictos', $L a$ Republica (28 August 2006) [Ramos, 'Yanacocha paraliza operaciones'].

107. Á Páez and W Castro, "Forza" no ha sido exculpada', La Republica (8 December 2006); M Salazar, 'El último guardián de las aguas', La Republica (10 September 2006).

108. Ibid.

109. Ibid.

110. Ramos, 'Yanacocha paraliza operaciones', supra n 106; Ramos, 'Yanacocha anuncia suspensión total de sus actividades', La Republica (28 August 2006) ['Yanacocha anuncia suspensión'].

111. M Salazar, 'Yanacocha amenaza con paralizar todas sus operaciones si continúan protestas', La Republica (28 August 2006).

112. Resumen Informativo - Cajamarca, Primer Informe 2011, online: Observatorio de Conflictos Mineros en el Perú <http://www.muqui.org/observatorio/OBSERVATORIOENERO2011/ Observatorio_enero_2011.htm\#ACAJAMARCA>.

113. Documents on file with author: Gerencia de Asuntos Externos de Yanacocha, Comunicado Especial: Nota de Prensa (4 August 2006); Gerencia de Asuntos Externos de Yanacocha, Comunicado Especial: Nota de Prensa (9 August 2006); Gerencia de Asuntos Externos de Yanacocha, Comunicado Especial: Nota de Prensa (23 August 2006).

114. E Camacho, 'Yanacocha suspende operaciones y congela diálogo con campesinos', La Republica (29 August 2006).

115. MA Arana Zegarra, Ampliación de Manifestación, Quinta Fiscalía Provincial Penal (13 April 2007) [Arana, Ampliación de Manifestación].

116. Camacho, supra n 114.

117. Arana, Ampliación de Manifestación, supra n 115. 
office, until Campesinos from several rural communities came to their rescue chasing away Yanacocha's employees.

These marches heralded the escalation of 'Operación Diablo', a systematic programme of intimidation, death threats and defamation, primarily targeting GRUFIDES personnel, but extending to approximately 30 other related local environmentalists and Campesino leaders. Operación Diablo also included the constant surveillance and digital documentation of the daily activities of GRUFIDES personnel. ${ }^{118}$ At the same time, the telephones in the GRUFIDES office were tapped. ${ }^{119}$ This intense harassment and surveillance of GRUFIDES continued for a period of months without police investigation.

On one occasion, GRUFIDES personnel apprehended an individual who had been following them and took the suspect to the police. ${ }^{120}$ Yet before being questioned, this individual escaped police custody in full view of the responsible police officers. A bystander with a camcorder filmed the complicity of the police in this escape. ${ }^{121}$ On a second occasion, GRUFIDES personnel apprehended another individual who had been filming and following them. ${ }^{122}$ Upon being detained, this individual confessed that he was in the employ of C\&G Investigations, a private investigation company owned and operated by a retired former Capitan of the Peruvian National Police Force. ${ }^{123}$

The circumstances of this second apprehension forced police and a prosecutor to search the $C \& G$ offices where they discovered and confiscated seriously incriminating evidence. ${ }^{124}$ This included computers and other digital devices containing hundreds of photographs of GRUFIDES personnel and other activists. ${ }^{125}$ Also found were electronic and hard copies of hundreds of police-styled surveillance reports that documented the activities of these activists. ${ }^{126}$ The information in these reports indicated that they were regularly submitted by $\mathrm{C} \& \mathrm{G}$ employees to a pseudonymed individual in accordance with the terms of Operación Diablo ${ }^{127}$ Records of emails exchanged and payments made for services between Forza and C\&G were also found on the $C \& G$ premises. ${ }^{128}$ Shockingly, the police returned this incriminating

118. 'Amenazan a Sacerdote y ONG que defienden medio ambiente', La Republica (16 November 2006); 'Denuncian acoso al padre Arana', La Republica (17 November 2006); 'Todo empezó después de Combayo', La Republica (4 December 2006).

119. See infra section 4.3 for a discussion regarding the evidence that links this telephone tapping to Operación Diablo.

120. Quinta Fiscalía Provincial Penal de Cajamarca, Resolución N $N^{o}$ 52-2007-MP-5FPPC (9 March 2007).

121. Quinta Fiscalía Provincial Penal de Cajamarca, Acta Fiscal de Visualización, Trascripción e Impresión de Imágenes (23 April 2007).

122. 'Detienen a camarógrafo por filmar a Arana', Diario El Sol (15 November 2006).

123. MÁ Saldaña Medina, Manifestación, Quinta Fiscalía Penal de Cajamarca (14 November 2006).

124. Fiscal Adjunto Provincial, Quinta Fiscalía Penal de Cajamarca, Acta de Registro Domiciliario (14 November 2006).

125. Quinta Fiscalía Provincial Penal de Cajamarca, Resolución $N^{o}$ 018-2007-5FPPC (25 January 2007) [Resolution No 18].

126. Fiscal Adjunto Provincial, Quinta Fiscalía Penal de Cajamarca, Acta de Apertura de Sobre Lacrados (11 December 2006).

127. E Cruz and C Romero, 'Evidencias vinculan a empresa Forza con Operación El Diablo', La Republica (6 December 2006).

128. Resolución $N^{o} 18$, supra n 125; Fiscal Adjunto Provincial, Quinta Fiscalía Penal de Cajamarca, Acta de Constancias de Impresiones de Archivos (15 November 2006). 
evidence directly to $\mathrm{C} \& \mathrm{G}$ shortly after its discovery. The surveillance information documenting the private and public lives of GRUFIDES personnel was returned completely intact. Further, the computer hard drives were returned before the vast majority of the incriminating information was fully reviewed, recorded or copied by police. ${ }^{129}$

In light of the refusal of the police to properly investigate Operación Diablo, anonymous sources submitted further evidence directly to GRUFIDES as well as to reputable journalists in Lima who were conducting their own investigation. ${ }^{130}$ This evidence included Forza's operational manual, which revealed that the pseudonym of the individual to whom $C \& G$ had directed its reports corresponded to Forza's head manager of operations. This evidence included a PowerPoint presentation entitled 'Existing Threats to Yanacocha 2006' and 'Principal Leaders in Cajamarca that Oppose Yanacocha's Mining Activity'. ${ }^{131}$ These electronic documents contained photographs and descriptions of GRUFIDES personnel along with leaders from other local environmental and Campesino organizations. ${ }^{132}$ Among them was a photograph of the Campesino leader Esmundo Becerra who was active in the defence of the Negritos' territory from Yanacocha's expansion. Esmundo was later assassinated in December of that year. ${ }^{133}$

The GRUFIDES Case alleges that there is clear and compelling evidence that Operación Diablo was executed by Yanacocha's private security company Forza who in turn sub-contracted $\mathrm{C} \& \mathrm{G}$ Investigations. In spite of the overwhelming evidence linking C\&G, Forza, and Yanacocha to Operación Diablo, the Peruvian justice system has consistently refused to properly investigate and criminally prosecute those responsible. ${ }^{134}$ On the contrary, as described above, it is well documented that on at least two occasions the police force was complicit in the crimes committed. ${ }^{135}$ Complaints filed by GRUFIDES in relation to police conduct in the course of the investigation have also been unsuccessful. ${ }^{136}$

\section{LEGAL PROCESS AND THE PRIVATE-PUBLIC CONVERGENCE}

The story behind the Negritos and the GRUFIDES Cases is told with special attention to the relationship between law and power, understood here as the way in which law is implicated in the rearrangement, maintenance and legitimation of power

129. ME Vásquez Chuquilín, Interponemos Queja de Derecho, Investigación No 2006-495 (28 May 2007).

130. Cruz, 'Nuevas Pruebas', supra n 95.

131. 'Presentan pruebas del espionaje contra defensores de medio ambiente', La Republica (6 December 2006); 'Hoy revelan más datos del reglaje a Padre Arana', La Republica (6 December 2006).

132. UN Working Group, supra n 86 at 49.

133. See: Frente de Defensa, supra $\mathrm{n} 68$ and accompanying text.

134. Resolución $N^{o} 18$, supra n 125; Quinta Fiscalía Provincial Penal de Cajamarca, Resolución $N^{o}$ 76-2007-MP-5FPPC (21 May 2007); Primera Fiscalía Superior Penal de Cajamarca, Resolución $N^{o}$ 111-2007-MP-1FSEP-CAJ, Ingreso No 2006-495 (6 June 2007).

135. See nn 129, 130, 138 and accompanying text.

136. Raúl Fuentes Joseph, Comandante PNP, Secretario Ejecutivo, Secretaria General, Oficio $N^{o}$ 1980-2008-IGPNP/SEC-C, José Raúl Ubaldo Aliaga, Coronel PNP, Secretario GeneralDIRGEN PNP (19 August 2008); José Raúl Ubaldo Aliaga, Coronel PNP, Secretario General de la PNP, Dirección General, Oficio $N^{o}$ 163-2008-DIRGEN PNP/SG, Manuel Jesús Ordeñoz Reaño, Secretario General del Ministerio del Interior (25 August 2008). 
relationships. ${ }^{137}$ The socio-legal context provided in the Negritos Case chronicles how a process of legal reform changed the content of communal property rights, and the manner in which they could be legally constituted, acquired and transferred to third parties. These changes were juxtaposed with the legal context of the GRUFIDES Case, namely, the legislation that establishes how the private sector may avail itself of the coercive resources (security services) it requires to protect its property interests.

Building on this, the factual elements of each case reveal how private and public power 'converged' in the sense that the State and Yanacocha Mine engaged in a pattern of conduct that appeared to be mutually reinforcing. This occurred through the exchange of roles, responsibilities, resources and information, and through the facilitation of social and legal processes. Thus, the use of the term 'convergence' in this paper refers to the relationship generated by the tangible and symbolic practices of two specific actors, the Peruvian State and Yanacocha Mine. The argument that there is a 'convergence' of private and public power in this case study is an analytical conclusion based on publically available documentary sources that depict the contemporary practices of these two specific actors.

Like any other method of inquiry, this empirical approach has certain strengths and limitations. A case study such as this, of micro-level practices and their legal contexts cannot, in and of itself, directly support grander conclusions regarding the nature of the relationship between public and private power. This study does not therefore, purport to make a specific intervention into conceptual, historical, or normative theoretical debates. However, the empirical focus here on the mutual constitution of practices, power and law is nonetheless valuable, and perhaps even necessary, for the advancement of these theoretical debates. The relevance of this study to conceptual, historical, or normative approaches will be considered briefly in turn.

Conceptual studies regarding the private and public interrogate how we may know and define the content of these categories. ${ }^{138}$ The present study does not engage in this debate in that it does not attempt to define the private and public in general terms. But by documenting the actions, prerogatives, interventions and legal methods of Yanacocha Mine and the Peruvian State, it offers important insights which may feed into conceptual debates on the content of private and public power in the abstract, as well as in the context of societies with similarities to this case study.

Historical inquiries into the private and public are related to conceptual approaches to the extent that they may chronicle how the conceptual content and meaning

137. In this sense this study articulates with one of the modes of inquiry associated with the intellectual current known as Critical Legal Studies (CLS). One common concern among CLS scholars is the role that law plays to legitimate the constitution of power and power relationships. This approach politicizes law in that it takes the position that the values it represents and the outcomes it facilitates are not neutral but rather the result of political decisions and preferences, which are secured in the context of social and economic power relationships. For an overview of the history of CLS and a bibliography of its founding texts, see: Pierre Schlag, 'Critical Legal Studies' in SN Katz (ed), The Oxford International Encyclopedia of Legal History, Vol 295 (Oxford University Press, Oxford 2009).

138. For some examples of work that touches on these conceptual issues, see: D Drache (ed), The Market or the Public Domain: Global Governance and the Asymmetry of Power (Routledge, London 2001); C Cutler, 'Artifice, Ideology, and Paradox: The Public/Private Distinction in International Trade Law' (1997) 4 Review of International Political Economy 261; C Cutler, V Haufler and T Porter, Private Authority and International Affairs (SUNY Press, Albany 1999). 
assigned to these categories have changed over time. Such studies may attempt to explain the present in terms of the past, or may demonstrate the ruptures and discontinuities between the past and the present. ${ }^{139}$ In contrast, this case study assumes no particular relationship between the contemporary practices it describes and any historical counterparts. Accordingly, as used here, the term 'convergence' does not have a temporal or historical connotation. Nonetheless, this detailed investigation of the contemporary practices of the Peruvian State and a particular mining company may be of great interest to more extensive empirical projects seeking to uncover the nature of similar or relevant practices in comparable historical moments. ${ }^{140}$

Normative theories of the relationship between private and public power adopt particular conceptual definitions of these categories in order to identify the principles of legitimacy that should govern the exercise of power in a given society. ${ }^{141}$ In the political context investigated in this paper, the normative starting point is the Peruvian Constitution, which establishes the standards of a constitutional democracy. ${ }^{142}$ In this tradition, the state's legitimate exercise of power is secured through respect for democratic processes and adherence to the rule of law. ${ }^{143}$ Concomitantly, corporate power is legitimate to the extent that it respects the system of laws and norms articulated by its public counterpart. The rule of law principle requires the state, not only to adhere to its own laws, but also to enforce the law on non-state actors. The practices of the State and Yanacocha Mine documented in this study are of interest to normative modes of inquiry to the extent that they may offer insight into limitations and challenges faced by the rule of law principle in circumstances similar to those described in this case study.

Yet the relationship between law and private and public power is only part of the story told here. The account offered is also attentive to the negative consequences of the relationship between law and power for a particular group of actors located in the 'Third World' ${ }^{144}$ namely a Campesino Community and a group of environmental and

139. For one articulation of different methods of historical study, see M Foucault, The Archaeology of Knowledge (Tavistock Publications, London 1974).

140. For extensive discussions regarding the historical evolution of the state and the economy in Latin America, see R Thorp, Progress, Poverty and Exclusion: An Economic History of Latin America in the Twentieth Century (Inter-American Development Bank, Washington DC 1998); $\mathrm{V}$ Blumer-Thomas, The Economic History of Latin America since Independence, $2^{\text {nd }}$ Edition (Cambridge University Press, New York 2003). For similar work specifically related to Peru, see R Thorp and G Bertram, Peru 1890-1977: Growth and Policy in an Open Economy (Columbia University Press, New York 1978); R Thorp and M Paredes, Ethnicity and the Persistence of Inequality: The Case of Peru (Palgrave Macmillan, Basingstoke 2010).

141. The origins of this debate are typically attributed to Thomas Hobbes, Leviathan. Part I and II, AP Martinich (ed) (Broadview Press, Peterborough 2005).

142. Article 45 of the Political Constitution of Peru, 1993 declares that the power of the State emanates from the people and that those who exercise state power must do so within the limitations and according to the responsibilities that the Constitution and the law establish. Article 51 states that the Constitution prevails over other legal norms and laws. Article 200 provides for judicial oversight of any state action or legislation that is alleged to violate the terms of the Constitution.

143. James Tully, 'The Unfreedom of the Moderns in Comparison to their Ideals of Constitutional Democracy' (2002) 65 Mod L Rev 204 at 205. According to Tully, the principles of constitutionalism and democracy have emerged as the guiding norms for evaluating the legitimacy of the exercise of power in contemporary forms of political association.

144. This focus articulates with the concerns of an approach to legal study known as Third World Approaches to International Law (TWAIL). The unifying concern of TWAIL scholarship is that the international legal system is the product of a colonial history and that it 
human rights activists. The legal prism applied here construes these consequences in terms of the violation of legal rights, constitutional rights and international human rights law. However, while this paper evaluates the use of law to produce the violations alleged, it is also concerned with the means that law might offer these communities and groups to address the complaints they have against the State and Yanacocha Mine. Thus, at least in principal, law may serve as an instrument, both of power and of resistance to the exercise of power. Yet, in the practical contexts of the Negritos and GRUFIDES Cases, the efforts to date to use domestic law ${ }^{145}$ as a means of resistance have been unsuccessful. This observation raises the question of whether or not, and if so, under what conditions, the law may serve as an instrument of resistance to the particular configuration of power produced by the private-public convergence. While a full exploration of this question is beyond the scope of an empirical study such as this, this paper's concluding remarks will offer some further reflections in this regard.

The practices of mutual support, exchange and facilitation that characterize the private-public convergence in the Negritos and GRUFIDES Cases can be synthesized into four legal processes: (1) the dispossession of Campesino communal land; (2) the construction of formal consent to the elimination of Campesino rights; (3) the privatization of coercive force; and (4) the absence of an effective legal remedy. On the one hand, these processes are a product of the private-public convergence in that the practices that constituted the convergence evidently functioned to secure these four legal results. On the other hand, these processes also produce the convergence because they define the terms for the legal exercise of power and for the relationship between private and public actors with regard to two specific sites of power, namely property and the use of force. As such, these four processes produce, and are produced by, the private-public convergence. The remainder of this section will analyse the mutually reinforcing practices of the State and Yanacocha in the context of each of these legal processes.

\subsection{The dispossession of Campesino communal land}

The story of the Negritos Case shows how the actions of the State and the systemic bias in favour of individual title, inherent in Peru's land regime, facilitated the destruction of the Negritos Community's land interests to the benefit of Yanacocha. It documents the State's administrative decisions that purported to eliminate the Negritos Community's communal title and to substitute it with individual title. Further, it demonstrates the conditions in which individual title easily resulted in

works to disempower Third World peoples and intensify global inequality, see C Kamphuis, Book Review of The Third World and International Order: Law Politics and Globalization by A Anghie, B Chimni, K Mickelson and O Okafor (eds), (2010) 12 International Community Law Review 1-7. Authors in this literature have demonstrated particular concern for Third World social movements and the negative consequences of the international economic system, see for example, B Rajagopal, International Law from Below: Development, Social Movement and Third World Resistance (Cambridge University Press, Cambridge 2003); JT Gathii, 'Third World Approach to International Economic Governance' in R Falk (ed), International Law and the Third World: Reshaping Justice (Routledge-Cavendish Press, Abingdon 2008) 256.

145. Beyond these efforts, advocates have also attempted to use international public law and corporate social responsibility mechanisms. These will be discussed in greater detail in the conclusion to this paper. 
the disposition of Campesino land to foreign private investors. Finally, it reveals how both the State and Yanacocha controlled and coordinated the processes necessary to 'transfer' a portion of Negritos land interests to Yanacocha by way of an expropriation and a mining easement.

It is difficult to capture the deeper informal relationships between Yanacocha and the State that may be implicated in the destruction of the Negritos' communal land rights. To this end, the work of Jeffery Bury, an American geographer who has studied shifting land tenure patterns in Cajamarca, is helpful. According to Bury, Yanacocha secured the purchase of collectively managed land by initiating a series of rapid individual land-titling initiatives. In particular, Yanacocha's employees 'organized community meetings, transported people to the city in mine vehicles and ushered them through the land-titling process so that the mine could purchase their land. ${ }^{146}$ Bury concludes that Yanacocha became the principal agent effecting the consolidation of individual land tenure in the area of its planned operations. Bury's description of Yanacocha's informal role in promoting the privatization of collectively managed land in rural Cajamarca complements the documentation in the Negritos Case depicting the coordinated effort of the State and Yanacocha specifically in relation to Negritos communal land.

The transfer of Negritos land to Yanacocha consolidated a legal regime that allowed Yanacocha's shareholders to accumulate enormous wealth, converting it into one of the most profitable mining investments in the world. Yet payments made in exchange for Negritos land were grossly unjust and Negritos comuneros continue to experience among the highest levels of extreme poverty and unemployment in all of Peru. ${ }^{147}$ The lack of fair compensation and extremely unequal relative gains and losses suggests that the loss of Negritos communal land rights is appropriately described as a process that gave rise to a relationship of dispossession between Yanacocha and the Negritos Community.

The Negritos Case further alleges that in the course of eliminating the Negritos Community's land rights, the Peruvian State and Yanacocha violated, inter alia, the Negritos comuneros' right to collective property, to free, prior and informed consultation and consent, to fair and equitable compensation and to participate in the benefits of resource extraction on their land. These rights were protected in domestic legislation, the Peruvian Constitution, the American Convention on Human Rights ${ }^{148}$ and Convention $N^{o} 169$. The impugned conduct of Peruvian State officials in the Negritos Case resonates disturbingly with the observations, made decades prior, by the Inter-American Commission on Human Rights in its report Special Protection for Indigenous Populations, Action to Combat Racism and Racial Discrimination:

That for historical reasons and because of moral and humanitarian principles, special protection for indigenous populations constitutes a sacred commitment of the states;

That on various occasions this Commission has had to take cognizance of cases in which it has been verified that abuses of power committed by government officials responsible for

146. Bury, 'Mining Mountains', supra n 36 at 232.

147. The Negritos Community is emblematic of the widespread observation, made even by the World Bank itself, that the privatization of Campesino land in Peru has not benefited Campesino Communities who remain among the poorest, most marginalized members of society: see Hall and Patrinos, supra n 4.

148. American Convention on Human Rights, 1144 UNTS 123, OEA/Ser.L.V/II.82Doc.6 rev.1 at 25 . 
administrative work in connection with indigenous communities have caused very serious injury to the human rights of their members;

That these offenses against human rights are all the more reprehensible considering that they are committed by agents of the public power and have as their victims persons or groups for whom the effective exercise of their means of defense established by the laws of the respective states is particularly difficult... ${ }^{149}$

The Negritos Case places the contemporary socially disadvantaged situation of the Negritos Community in a historical legal context by documenting the legal processes that link this state of marginalization, not only to the practices associated with the private-public convergence, but also to the hacienda model of Peru's colonial history. This reveals that the contemporary convergence of private and public power functions to extend the colonial injustices that agrarian reform failed to remedy. Not only is private and public power converging to dispossess Campesino Communities of their land, this dispossession is made possible because of the unresolved legacy of colonialism. The objects of the dispossession in question are the Indigenous labourers of the former haciendas and their decedents. In this analysis, the law has functioned to install Yanacocha in Cajamarca as the modern inheritor of the colonial relationship enshrined in the former hacienda model. ${ }^{150}$ As a matter of legal history and as a result of legal processes, Yanacocha is the modern hacienda owner, or hacendado, made legitimate by modern law.

\subsection{The production of formalistic Campesino consent}

The modern hacienda model described above is insidious because it purports to derive its legality and legitimacy from the consent of the Negritos Community. The Negritos Case demonstrates how the State and Yanacocha converged to produce, in the most formalistic of terms, the ostensible 'participation' and 'consent' of the Community to its own dispossession and legal annihilation. Meetings were held, in some cases a relatively nominal amount of money changed hands, documents were signed, and the Negritos Community presumably 'agreed' to eliminate its land interests and renounce its rights as a Campesino Community. In legal terms, the State facilitated

149. OAS, Inter-American Human Rights Commission, Special Protection for Indigenous Populations, Action to Combat Racism and Racial Discrimination, OR OEA/Ser.P.AG/ Doc.305/72, rev 1, (1973) at 90-1 cited in F MacKay, A Guide to Indigenous Peoples' Rights in the Inter-American Human Rights System (Forest Peoples Programme, UK 2001) at 22, online: International Work Group for Indigenous Affairs <www.forestpeoples.org/documents/ law_hr/iachr_briefing_oct_01_eng.pdf> [MacKay, Guide to Rights]. The responsibilities of public officials to Indigenous people was reiterated in: OEA, Inter-American Commission on Human Rights, Report on the Situation of Human Rights in Ecuador, OR OEA/Ser.L/V/ II.96/Doc.10, rev 1 (1997).

150. Writing in the development literature, Anthony Bebbington suggests that corporate social responsibility programmes in Peru create an 'assemblage' that 'looks very much like a modern form of the hacienda model'. He describes this as 'a packet of interventions that combines market transactions and patronage relationships, and that in the process builds a wide-ranging web of relationships centered on the company.' He further claims that these programmes provide services and employment in a manner that is imbued with deeply retrograde attitudes toward Campesinos: see A Bebbington, 'Extractive industries and stunted states: conflict, responsibility and institutional change in the Andes' in R Ramen (ed), Corporate Social Responsibility: Discourses Practices and Perspectives (Palgrave MacMIllan, London 2010). 
the production of consent through the mechanisms of administrative law while Yanacocha obtained consent by directly negotiating with comuneros to exchange money for land on the 'free market'.

The Negritos Case alleges that the procurement of the Community's 'consent' violated domestic laws, not least of which being the norm that communal land cannot be alienated without a vote of two-thirds of the Campesino Community united in a General Assembly. ${ }^{151}$ It further alleges that the Peruvian State failed to fulfil its duty under the American Convention and Convention $N^{\circ} 169$ to ensure that any decisions of the Negritos Community regarding the possible elimination or reduction of its property rights are fully informed and freely made. The Inter-American Court has recognized that Indigenous property rights originate in Indigenous forms of land tenure, rather than state recognition. ${ }^{152}$ States have a duty to recognize and respect the collective aspects of these rights and put adequate measures into place to guarantee that communities enjoy their property rights in practice. ${ }^{153}$ The Inter-American Commission has declared that states must take special measures to ensure that Indigenous peoples are not deprived of their property except with fully informed consent, under conditions of equality, and with fair compensation. ${ }^{154}$ The Commission has defined fully informed consent to include, at a minimum, a situation where all of the members of a given community are fully and precisely informed about the nature and consequences of the process and have an effective opportunity to participate, individually or collectively, in the decision. ${ }^{155}$ The Inter-American Court has further stated that the State is responsible to ensure that prior to making a decision, Community members have knowledge of the possible risks, including any environmental and health risks, that the proposed mining project could involve. ${ }^{156}$ The provisions of the United Nations Declaration on the Rights of Indigenous Peoples ${ }^{157}$ approved by the UN General Assembly in 2007, further reflect these principles. ${ }^{158}$

The thin veneer of legality created by the production of consent quickly evaporates upon a substantive analysis of the Negritos Case on the basis of the applicable international and domestic human rights norms. The testimonial evidence collected by Bury and others affirms that the practices of State functionaries and Yanacocha officials in producing formal legal consent were unscrupulous at best and abusive at worst. The impossibility of free and informed consent is underscored by the continued existence of the Negritos Community as a cultural, sociological and political fact.

151. See: Campesino Communities General Law, supra $\mathrm{n} 11$.

152. Awas Tingni, supra n 17.

153. Indigenous Community of Yakye Axa (Paraguay) (2005), Inter-Am Ct HR (Ser C) No 125; The Court has also concluded that physical possession of a traditional territory is not a precondition for the existence of Indigenous property rights where the Indigenous community has involuntarily lost possession of its land: Indigenous Community of Sawhoyamaxa (Paraguay) (2006), Inter-Am Ct HR (Ser C) No 146.

154. Maya Indigenous Communities of the Toledo District v Belize (2004), Inter-Am Comm HR, No 40/04 [Belize Case]; Mary and Carrie Dann v United States (2002), Inter-Am Comm HR, No 75.

155. Belize Case, ibid at para 142.

156. Saramaka People (Surinam) (2007), Inter-Am Ct HR (Ser C) No 172 at para 134.

157. UNGAOR, 62 Sess, UN Doc A/61/L.67 (2007) 1.

158. The Declaration establishes that consultation to obtain Indigenous peoples' free and informed consent prior to carrying out any project affecting Indigenous land, particularly in connection with mineral resources, is the minimum standard for the survival, dignity and well-being of Indigenous peoples: ibid, arts 32(2), 43. 
Since the late 1990s, the Negritos Community has actively organized to defend its land from mining expansion and has sought to regain State recognition through formal legal channels. The response of the State and Yanacocha has ranged from indifference to repression. This reveals the contradictory approach to consent inherent in the private-public convergence: uninformed 'consent' to the elimination of rights is ushered through the legal system while the Negritos Community's vigorous and repeated demand to control the use of its land and participate in the benefits of Yanacocha's mining activities is ignored.

There is no doubt that, in the Negritos Case, the privatization of Campesino land cannot derive its legitimacy from any legally recognized notion of consent (given the deceptive and forcible nature of its production). This conclusion is relevant to current efforts to operationalize the concept of 'free, prior and informed consent' in international law. ${ }^{159}$ The observations made in the Negritos Case question the possibility of 'free consent' in a context where the processes of the private-public convergence that manufacture consent remain intact. The links between coercive practices and property relations, further depicted in the GRUFIDES Case, are explored in greater detail in the following section.

\subsection{The privatization of coercive force}

The events outlined above strongly support the conclusion that the on-going social conflict in Cajamarca originates in the unresolved violations that occurred during Yanacocha's early land acquisitions from Campesino Communities. ${ }^{160}$ This hypothesis suggests a link between the alleged human rights violations in the Negritos Case, associated with the dispossession of land, and those of the GRUFIDES Case, linked to the privatization of force. It is clear that GRUFIDES began to advocate on behalf of Campesino Communities in the absence of a State authority willing to recognize the needs of Campesino Communities and to take their interests into consideration. The success of GRUFIDES in supporting Campesino Communities, and the intensification of demands by Campesino Communities were met with organized repression on the part of Yanacocha's private security companies. The GRUFIDES Case thus highlights some of the overtly coercive aspects of the private-public convergence.

159. See J Anaya, 'Indigenous Peoples' Participatory Rights in Relation to Decisions about Natural Resource Extraction: The More Fundamental Issue of What Rights Indigenous Peoples Have in Lands and Resources' (2005) 22 Arizona Journal of International and Comparative Law 8. For an overview of the development of the Indigenous rights movement on Latin America, see Karen Engle, The Elusive Promise of Indigenous Development: Rights Culture, Strategy (Duke University Press, Durham 2010). This debate recently became even more relevant in Peru due to the recent promulgation of a law recognizing Indigenous peoples' right to consultation: Law for the Right to Consultation, supra n 3. Introduced by the newly elected 2011 government, this law represents, at least formally, a dramatic shift in domestic policy after more than two decades of consecutive neo-liberal governing parties. In 2011 Ollanta Humala was elected President of Peru on a platform that promised to introduce regulatory measures to promote a more equitable distribution of wealth, especially in the area of resource extraction. However, by the close of 2011, Humala had already become a major disappointment to his supporters on the political left due to his militarized response to social protest and his stance in favour of controversial resource extraction projects: S Boyd, 'Business as Usual: Peru's New President Leaps to the Right', New Internationalist Magazine (7 December 2011), $<$ http://www.newint.org/features/web-exclusive/2011/12/07/peru-new-president-mine-strikes > 160. This conclusion is also reached by Meléndez, supra n 75 at 325. 
As the State facilitated the acquisition of land by Yanacocha, it also permitted for the expansion of the use of private coercive power, which has in turn been used to repress the rise in Campesino protest and opposition to mining. As in the Negritos Case, in many cases the root cause of this opposition is the dispossession of Campesino land in favour of mining interests. In this sense there is a relationship between the overt and covertly coercive aspects of the private-public convergence.

The GRUFIDES Case depicts a deep interpenetration between the State's coercive power and Yanacocha's economic power. As described previously, the police force in Cajamarca has been partially privatized in order to serve the needs of Yanacocha. Peruvian legislation permits the mining company to hire off-duty police officers to perform security services while using state-owned property. It further allows Yanacocha to partially fund the police force as an institution, through the formation of a private cooperation agreement between the two parties.

Moreover Yanacocha's private security companies are interwoven with public actors, attributes and roles. As discussed above, Forza is owned and managed by former police and military personnel. Forza officers protect Yanacocha's most valuable property, including its mining facilities, its gold refinery and explosive storehouses. ${ }^{161}$ Yet Yanacocha has not delineated the domain and scope of action of Forza officers in relation to that of police officers. ${ }^{162}$ For example, Forza agents worked alongside off-duty Yanacocha-paid police officers to control the Combayo road blockade. It has not been clarified whether it was Forza or police officers that shot and killed the Campesino Isidro Llanos while he participated in the Combayo road blockade. Further, Yanacocha does not have procedures to ensure that Forza officers have actually been discharged from military or police service and have a clean criminal record. ${ }^{163}$

Yanacocha also employs at least two private intelligence companies, charged with collecting information in both rural and urban Cajamarca. ${ }^{164}$ This is likely the same web of intelligence that contributed to the production of the PowerPoint presentation entitled 'Threats to Yanacocha', mentioned above, which profiled Negritos comunero Esmundo Becarra, who was later assassinated. In this respect, Yanacocha has no procedures in place to ensure that that this does not occur. ${ }^{165}$ Further, it was discovered in 2009 that a third intelligence agency, Business Track Resources, wire-tapped GRUFIDES' telephone lines in 2006, precisely while Operación Diablo was in full effect. ${ }^{166}$ It is not known who paid Business Track Resources to undertake these

161. Ibid.

162. Ibid at 15 .

163. Ibid. In this regard, disturbing photographs were made public in January 2009 that connect police and Forza officers to the torture of at least 29 comuneros who were protesting the activities of Majaz Mine in a region that neighbours Cajamarca. These events occurred in July and August 2005, just prior to the violations alleged in the GRUFIDES Case. See Elizabeth Prado, 'Minería y Violaciones de Derechos Humanos: El Caso de Minera Majaz, Piura Perú', La Republica (9 January 2009). For an extensive background report on the conflict, see: Bebbington et al, Rio Blanco Project, supra $\mathrm{n} 83$. At the time that these crimes were committed, Majaz Mine was a wholly owned subsidiary of the British mining company Monterrico Metals: Mario Alberto Tabra Guerrero \& Others v Monterrico Metals PLC \& Rio Blanco Copper SA, [2009] EWHC 2475 High Court of Justice, Queen's Bench Division.

164. Costa, Comprehensive Review, supra n 103 at 11.

165. Ibid at 15 .

166. Expediente $\mathrm{N}^{\circ}$ 527-09, Thirty-Fourth Criminal Court of Lima (30 November 2009). 
criminal acts, but it is known that Forza was one of its corporate clients. ${ }^{167}$ Like Forza, Business Track Resources was founded and managed by former military personnel.

On the basis of the foregoing, it appears that while private interests increasingly control public coercive power, private coercive power is also assuming a somewhat public character. In addition, an underlying irony accompanies this convergence. As discussed above, the relative proportion of the State's coercive function has been reduced as private security companies take a more prominent role in the exercise of force and intelligence gathering. However, the level of repression permissible when state actors exercise coercive force has also increased. Criminal code offences have been broadened to include public protest, while on-duty police and military officers enjoy a codified right to impunity when committing murder in the course of "controlling' protest. Thus, while the coercive arm of the State has been privatized, it has also been simultaneously strengthened.

\subsection{The absence of effective domestic legal remedies}

Both the GRUFIDES Case and the Negritos Case are last resort legal actions pursued because of the absence of effective domestic legal remedies to address the alleged human rights violations. Since 2006 the Negritos Community has participated in numerous administrative processes in an effort to obtain State recognition of its legal personhood and land rights, in particular with respect to the Reserve Area. In response, the State has consistently denied the existence of the Community's legal personhood and refused to recognize any associated rights. In the legal system, the Community has encountered significant delays and procedural obstacles in its criminal and civil lawsuits to defend the Reserve Area. Finally, as described above, the Negritos Community has sent countless letters to Yanacocha, raising a range of related complaints and asking the company to refrain from purchasing Negritos land. ${ }^{168}$ These efforts have been similarly fruitless. On one occasion, Yanacocha informed state officials that it had fulfilled all of its commitments and that it did not recognize the Negritos Community as such. ${ }^{169}$

As a result, the Negritos Community, like other communities, has regularly resorted to public protest. The State's reliance on GRUFIDES to mediate the Quilish and Combayo conflicts demonstrates its inability on these occasions to effectively resolve conflict between mining companies and social movements. One obvious explanation for this is that Yanacocha's enormous economic power has created the perception, if not the reality, that the State is not impartial. Not only has Yanacocha financed the operational costs of public offices and community dialogue processes, ${ }^{170}$

167. Á Paez, 'Spying on Social Movements', Inter Press Service (12 March 2009), online: Inter Press Service The Story Underneath <http://ipsnews.net/print.asp?idnews=46090>.

168. On file with author: Comunidad Campesina San Andrés de Negritos, Solicitud, Gerente General de Asuntos Externos y Comunidades, Minera Yanacocha SRL (3 January 2008); Minera Yanacocha SRL, Carta Notarial, Comunidad Campesina San Andrés de Negritos (22 August 2007); Junta Directiva de la Comunidad Campesina San Andrés de Negritos, Escrito, Gerente General de Asuntos Externos y Comunidades de Minera Yanacocha (3 January 2008).

169. Ministerio de Energía y Minas, Oficina General de Gestión Social, Informe Trimestral Octubre - Diciembre 2009 at 40.

170. Bebbington et al, 'Movimientos sociales', supra n 63 at 220. 
the company also funds the Peruvian police force as already discussed. However, given the dimensions of the private-public convergence described throughout this paper, a further conclusion must be drawn, namely, that the State is unable effectively to address the demands of mining-affected communities precisely because of its legal and administrative complicity in the dispossession that these communities are reacting against. Stated differently, the Peruvian State's unresponsiveness results, at least in part, from the convergence of public and private power in relation to Campesino land. The Negritos Case provides a particularly stark example of this.

Building on this, the GRUFIDES Case suggests that the complicity of the Peruvian State extends to the criminal conduct of Yanacocha's private security companies. The police force refused to provide GRUFIDES with adequate protection in the face of the openly hostile anti-GRUFIDES marches. Police officers then permitted the escape of a known suspect. Finally, the prosecutor returned incriminating evidence to Yanacocha's allegedly subcontracted private security companies and resolved not to prosecute the perpetrators of Operación Diablo. Likewise, the deaths of Esmundo Becerra and Isidro Llanos have not been prosecuted. Notably, the death of Combayo Campesino Isidro Llanos has been addressed by the private mechanism of voluntarily corporate responsibility rather than criminal prosecution: Yanacocha privately settled with the Campesino family of Isidro Llanos while Forza claims that it now funds a local day care facility in Combayo. ${ }^{171}$

It has been observed that pro-investment neo-liberal law reform, particularly in the area of mining, has undermined the State's capacity to govern. ${ }^{172}$ The GRUFIDES and Negritos cases demonstrate that in the wake of neo-liberal mining-oriented reforms, the criminal justice system and the administrative law system appear to be wholly unable to address the human rights concerns raised by the private-public convergence in this study. A long line of inter-American jurisprudence, beginning with the Velasquez Rodriquez Case (Honduras) in 1988, has affirmed that the State has a fundamental duty to prevent, investigate and punish all criminal acts. ${ }^{173}$ This jurisprudence further establishes that the human rights violations of private actors become the State's responsibility in international law when it fails to fulfil this duty. Indeed the fulfilment of this duty is precisely what legitimates the State's use of coercive power in the first place. Thus, to the extent that the Peruvian criminal justice system is unable to hold private investors accountable for the criminal conduct attributed to their private security forces, the State fundamentally loses its democratic legitimacy.

In the face of this situation, the claimants behind the GRUFIDES and the Negritos cases face the very real possibility that the alleged perpetrators of these human rights violations will continue to enjoy impunity. Having exhausted all domestic remedies, the only legal recourse now available to the GRUFIDES claimants is their petition to the Inter-American Commission on Human Rights, filed in May 2009. As described above, this petition alleges that the State has failed properly to investigate, prosecute and sanction the individuals and institutions responsible for Operación Diablo, and further, that the State was complicit in these acts.

171. 'Combayo-Yanacocha: hora de acuerdos', La Republica (5 September 2006); Seucritas Perú, Responsabilidad Social: online: Securitas <http://www.securitas.com/pe/es-pe/AboutUs/Responsabilidad-Social/>. The existence of this daycare has not been confirmed by local sources.

172. Campbell, supra $\mathrm{n} 87$; Bebbington et al, 'Contention and Ambiguity', supra $\mathrm{n} 39$ at 987. 173. Velásquez Rodríguez (Honduras) (1988) Inter-Am Ct HR (Ser C). 
However the Negritos Community may have a final domestic legal avenue available in the form of the constitutional amparo action. The amparo in Peruvian law is analogous to a common law application for judicial review. According to the Political Constitution of Peru, 1993, the amparo offers a declaratory remedy against any authority, public functionary or legal person who violates or threatens to violate another party's constitutional rights. ${ }^{174}$ According to the Constitutional Court of Peru, the international human rights treaties that the State has ratified are incorporated into the Constitution thereby creating enforceable rights. ${ }^{175}$ This provides the legal basis for the Negritos Community to claim that both the State and Yanacocha are responsible for ongoing violations of the Community's rights as protected by the Peruvian Constitution, the American Convention on Human Rights, and Convention $N^{o} 169$. However, the procedural and evidentiary requirements of the amparo action are not sympathetic to the complex historical and cultural realities of a Campesino land rights claim and may prove to be an insurmountable obstacle to such a claim. Even if the Community were to overcome these procedural challenges and successfully obtain an amparo remedy, such a remedy is declaratory and the enforcement of a favourable decision would rely on the political will of the Peruvian administrative system. Likewise, decisions of the Inter-American Court and Commission lack an enforcement mechanism and their implementation is a question of political will. Given the nature of the private-public convergence, it is questionable how responsive Peru's administrative and judicial system will be in both cases. This concern is taken up in the concluding remarks that follow.

\section{CONCLUSION: LAW AND RESISTANCE TO THE PRIVATE-PUBLIC CONVERGENCE?}

Like the communities of Negritos, Quilish, and Combayo profiled in this article, communities in the Americas, many of which are Indigenous, are now regularly demanding that mining development not be permitted without their free, prior and informed consent. ${ }^{176}$ When public and private institutions fail to respond to this demand, these communities have assumed significant risks and sacrifices in order to physically block mining activity. In many cases community leaders and protestors have lost their lives, been imprisoned, and suffered physical injury. But neither these serious risks, nor the spectre of corporate impunity, appear to deter these social movements. Nonetheless,

174. Political Constitution of Peru, 1993, art 200(2); Constitutional Procedural Code, Law No 28237.

175. STC No 0025-2005-PI/TC (25 April 2006) Constitutional Court of Peru, at para 33; STC No 003343-2007-PA/TC (19 February 2009) Constitutional Court of Peru, at para 31.

176. Some examples of many are: Tambogrande, Peru in 2002: 'Tambogrande Speaks Out' (20 June 2002), online: Oxfam America http://www.oxfamamerica.org/newsandpublications/ news_updates/archive2002/art2763.html; Ontario, Canada in 2008: Kitchenuhmaykoosib Inninuwug (KI), News Release, 'Aboriginal Leaders Face Jail Time in Spreading Disputes over First Nations Rights and Mining Claims: Consultation and Conservation Demands Conflict with Outdated Mining Law across Canada’s Boreal Forest' (25 January 2008); Ardoch Algonquin First Nations, Press Release, 'Jailing Aboriginal Leaders to Promote Uranium Mining in Ontario’ (19 February 2008); San Marcos, Guatemala in 2005: Shin Imai et al, 'Breaching Indigenous Law: Canadian Mining in Guatemala' (2007) 6 Indigenous Law Journal 101; Majaz, Peru in 2005, Bebbington et al, Rio Blanco Project, supra n 83; Cotacachi, Ecuador in 2005: Bebbington et al, 'Movimientos sociales', supra n 63. 
it is concerning that, at least in Peru, over ten years of public protest and activism has produced very little real change to public policy on mining. ${ }^{177}$

This lack of policy change, together with the failures of domestic legal norms and institutions such as those depicted in this case study, has led mining-affected communities to appeal to international human rights institutions. However, international human rights institutions are not endowed with enforcement mechanisms beyond the moral and political pressure that an unfavourable pronouncement may create. In this context, state compliance with orders issued by the Inter-American Court of Human Rights suffers from numerous deficiencies and rates of full compliance are extremely low. ${ }^{178}$ The authors of an extensive study of these compliance issues conclude that in order for appeals to the Inter-American Court effectively to combat impunity, they must be accompanied by 'coordinated, long-term advocacy strategies' which include social mobilization, strategic policy pressure, the media, and transnational advocacy networks. ${ }^{179}$

This thesis was recently put to the test in circumstances that bear significant resemblance to those described in this paper. In 2007, Indigenous communities adversely affected by the Canadian-owned Marlin Mine in Guatemala presented a petition to the Inter-American Commission alleging, among other things, that the State had failed to consult communities, and obtain their consent, with regard to the mine in question. ${ }^{180}$ This petition put in motion the first example of a high profile standoff in the inter-American human rights system between a powerful transnational social movement and foreign mining interests.

In 2010, the Commission responded by issuing precautionary measures ordering Guatemala to temporarily suspend all mining operations pending its review of their effect on the environment and communities affected. ${ }^{181}$ Guatemala failed to comply with this request and the following year it petitioned the Commission to declare the precautionary measures without further effect. ${ }^{182} \mathrm{~A}$ few weeks later, the mining company in question, Goldcorp, reported to its shareholders that it expected the precautionary measures to be lifted at the end of 2011. ${ }^{183}$ As Goldcorp predicted, the

177. Bebbington et al, 'Contention and Ambiguity', supra n 39 at 983 . It remains to be seen whether or not the newly elected left leaning government will introduce policies that produce substantive changes in these areas.

178. JL Cavallaro and S Brewer, 'Reevaluating Regional Human Rights Litigation in the Twenty-First Century: The Case of the Inter-American Court' 102 (2008) The American Journal of International Law 768 at 786.

179. Ibid at 788 .

180. Annual Report of the Inter-American Commission on Human Rights 2010 (Organization of American States, Washington DC 7 March 2011) at 5, Precautionary Measure 35.

181. Ibid.

182. Comisión Presidencial Coordindora de la Politica del Ejecutivo en Materia de Derechos Humanos, Letter to Minister External Relations, 'El Estado de Guatemala a la Ilustre Comisión Interamericana de Derechos Humanos presenta información adicional y observaciones en el procedimiento de Medidas Cautelares MC-260-07 a favor de 18 Comunidades de los Pueblos Mayas Mam y Sipakapense de los municipios de San Miguel Ixtahuacán y Sipacapa, ambos del departamento de San Marcos' (11 July 2011) online: COPREDEH <http://copredeh.gob.gt>. Also see J Roundell, 'Social Disclosure for Mining Companies: Holding Goldcorp to Account 2' (8 April 2012) [unpublished paper].

183. Goldcorp Inc, Management Discussion and Analysis, 'Financial Condition and Results of Operations for the Three and Six Months Ended June 30, 2011' (27 July 2011) online: SEDAR $<$ http://www.sedar.com>. Also see Roundell, ibid. 
Commission removed its order to suspend operations at the end of that year. ${ }^{184}$ Critics of the Commission's retraction have raised concerns about its capacity to withstand the political pressure associated with claims that directly impact foreign resource extraction projects, especially those that enjoy state support from both the country hosting the project, and the mining company's home country. ${ }^{185}$ The Commission's decision is all the more notable given that the local social movement and the extensive transnational advocacy network dedicated to the Marlin Mine case are relatively powerful compared to other movements and networks working on similar issues in the Americas. ${ }^{186}$

Corporate social responsibility is the private counterpart to public international human rights law where alleged human rights violations involve transnational corporations. ${ }^{187}$ Corporate social responsibility principles and norms often draw upon or adapt international human rights principles. These regimes are voluntary and lack both enforcement mechanisms and, in many cases, independent adjudication and evaluation of compliance.

Yanacocha is currently 'governed' by six of the most significant corporate social responsibility regimes. ${ }^{188}$ To date, local communities and their advocates have invoked two of these mechanisms to address a range of concerns related to Yanacocha's operations. ${ }^{189}$ However, one study of the outcomes of these complaints concluded

184. Inter-American Commission on Human Rights, 'Precautionary Measures Granted by the Commission during 2010, PM 260-07 - Communities of the Maya People (Sipakepense and Mam) of the Sipacapa and San Miguel Ixtahuacán Municipalities in the Department of San Marcos, Guatemala' online: OAS <http://www.oas.org/en/iachr/decisions/precautionary.asp>. 185. Center for International Environmental Law (CIEL) and MiningWatch Canada, News Release, 'Human Rights Commission's Climbdown a Wake-up Call for Human Rights Defenders in the Americas, Not Indicator of Goldcorp's Performance' (5 January 2012), online: $<$ http://www.miningwatch.ca/news/wake-call-human-rights-defenders-americas-not-indicatorgoldcorp-s-performance>.

186. For discussions referencing the local and international activism that has been directed toward Marlin Mine, see S Imai et al, supra n 176; AM Fulmer, 'La consulta a los pueblos indígenas y su evolución como herramienta de negociación política en America Latina: Los casos de Perú y Guatemala' 68 (2011) Apuntes Revista de Ciencias Sociales 37; T Ward, 'The Right to Free, Prior, and Informed Consent: Indigenous Peoples' Participation Rights within International Law' (2011) 10:2 Northwestern Journal of International Human Rights 54.

187. CA Williams, 'Civil Society Initiatives and "Soft Law" in the Oil and Gas Industry' (2003-2004) 36 NYUJ Int'l L \& Pol 457; D Graham and N Woods, 'Making Corporate Self-Regulation Effective in Developing Countries' (2006) 34 World Development 868; A Reinisch, 'The Changing International Legal Framework for Dealing with Non-State Actors' in P Alston (ed), Non-State Actors and Human Rights (Oxford University Press, New York 2005) 37.

188. For example, Yanacocha's majority shareholder, Newmont, has directly signed onto: (1) the United Nations Global Compact; (2) the Global Reporting Initiative; (3) the Voluntary Principles for Security and Human Rights in the Extractive Industry; and (4) the Position Statement on Mining and Indigenous Peoples of the International Council on Mining and Metals. Yanacocha would also be governed by the corporate responsibility regimes created by the Organisation for Economic Co-operation and Development and the World Bank.

189. Three complaints against Yanacocha have been filed with the International Finance Corporation office of the Compliance/Advisor Ombudsmen: see Office of the Compliance Advisor/ Ombudsmen, CAO Cases: Latin America \& the Caribbean, online: <http://www.cao-ombudsman. org > (follow 'Case' hyperlink; then follow 'Latin American \& Caribbean'); Yanacoch-01/ Cajamarca, CAO, online: <http://www.cao-ombudsman.org/cases/case_detail.aspx?id=110>; 
that they failed to address the underlying issues of impunity and that the appeal to these mechanisms by advocates might in fact perpetuate the conceptual and practical conflation of private and public power. ${ }^{190}$ Adding to these findings, the observations taken from the Negritos and GRUFIDES cases suggest that, in its current conception, corporate social responsibility is inherently unable to remedy the central problem in these cases, namely the illegal acquisition of land and the criminal exercise of coercive force. These mechanisms are simply not vested with the power or the frameworks necessary to mandate the redistribution of resources or the imposition of criminal sanctions.

The argument made in this article is that the private-public convergence both produces, and is produced by, particular domestic legal processes. These processes are important, not only because they constitute power, but also because they legitimate its formation and exercise. The processes identified in this study are also rife with contradictions. So-called security services are regulated and subjected to private contracts, while the exercise of force evades judicial investigation and oversight. Legal processes produce consent, while the law cannot respond to repeated expressions of community will. In view of the serious practical limitations of international human rights law and corporate social responsibility, it may be strategic, or even necessary, for lawyers and legal scholars interested in questions of resistance to concentrate their resources and creative energy on the micro-level legal processes that help constitute and legitimate the private-public convergence. Illuminating and articulating their contradictions offers a practical and non-ideological means of challenging the legitimacy of the practices that constitute the private-public convergence. Far away from the rhetoric and ideals of international human rights or corporate social responsibility mechanisms, these domestic legal processes constitute the immediate legal battleground for the tangible power struggles that social movements must confront as part of their daily material and symbolic reality. This study suggests that the constitution of property rights and the exercise of coercive force are fundamental aspects of these struggles.

Yanaacocha-02/Cajamarca, CAO, online: <http://www.cao-ombudsman.org/cases/case_detail. aspx?id=111>; Yanacocha-03/Cajamarca, CAO, online: <http://www.cao-ombudsman.org/ cases/case_detail.aspx?id=112>. Oxfam America filed a complaint against Yanacocha under the Voluntary Principles for Security and Human Rights: see Oxfam America, Press Release, 'Oxfam Calls on Mining Company to Respect Human Rights' (1 July 2009), online: <http:// www.oxfamamerica.org/press/pressreleases/oxfam-calls-on-mining-company-to-respect-humanrights>.

190. Kamphuis, supra n 103. 